\title{
亚洲棉短线突变体纤维发育及其差异基因表达分析
}

\author{
王晓阳 ${ }^{1}$ 王丽媛 ${ }^{1}$ 潘兆娥 ${ }^{1}$ 何守朴 ${ }^{1}$ 王 骁 ${ }^{1}$ 龚文芳 ${ }^{1,3, *}$ 杜雄明 ${ }^{1,2, *}$ \\ 1 中国农业科学院棉花研究所 / 棉花生物学国家重点实验室, 河南安阳 $455000 ;{ }^{2}$ 棉花生物学国家重点实验室郑州研究基地 / 郑州大 \\ 学, 河南郑州 $450001 ;^{3}$ 中南林业科技大学 / 经济林培育与保护教育部重点实验室, 湖南长沙 410004
}

摘 要: 棉花纤维是重要的天然纺织材料, 是最长的单细胞, 是研究纤维发育的良好材料。本研究以亚洲棉短线突变 体(FZ)及其野生型 $(f z)$ 为材料, 结合扫描电镜、石蜡切片、RNA-seq 技术, 解析棉花短线起始的可能机制。与野生型 $(f z)$ 的 $0 \mathrm{DPA}$ 时期胚珠相比, 突变体的胚珠在该时期仅有少量的纤维起始。在 $+3 \mathrm{DPA}$ 时, 突变体没有短线细胞起始, 仅 有长纤维细胞, 而野生型有大量的短纤维细胞和长纤维细胞。对这 2 个材料的 0DPA、+3DPA、+5DPA 和 $+8 \mathrm{DPA}$ 胚珠 差异基因分析结果显示, 在短线突变体(FZ)和野生型 $(f z)$ 的 4 个纤维发育时期共挖掘出 3780 个差异表达基因, 其中 0DPA 时 差异基因数目最少, 随着胚珠发育时间的延长, 差异基因的数目逐渐增加。KEGG 分析发现这些基因主要参与蜡质、角 质生物合成, 以及苯丙烷代谢和植物信号传导过程。共表达趋势分析显示, 在突变体 $+3 \mathrm{DPA}$ 上调的差异基因中, 参与离 子结合、MAPK 级联反应、氧化还原活性和转录调控的基因表达受到正影响(表达水平提高), 造成突变体短线纤维不能 正常起始。这些结果描述了二倍体亚洲棉短线起始的动态变化, 可为进一步研究棉纤维发育提供参考。

关键词: 亚洲棉; 短线突变体; 差异表达基因; 共表达趋势

\section{Analysis of differentially expressed genes and fiber development in Gossypium arboreum fuzzless mutant}

\author{
WANG Xiao-Yang ${ }^{1}$, WANG Li-Yuan ${ }^{1}$, PAN Zhao-E ${ }^{1}$, HE Shou-Pu ${ }^{1}$, WANG Xiao ${ }^{1}$, GONG Wen-Fang ${ }^{1,3,}{ }^{*}$, and \\ DU Xiong-Ming ${ }^{1,2}, *$

\footnotetext{
${ }^{1}$ Institute of Cotton Research, Chinese Academy of Agricultural Sciences / State Key Laboratory of Cotton Biology, Anyang 455000, Henan, China; ${ }^{2}$ Zhengzhou Research Base, State Key Laboratory of Cotton Biology / Zhengzhou University, Zhengzhou 450001, Henan, China; ${ }^{3}$ Key Laboratory of Cultivation and Protection for Non-wood Forest, Ministry of Education / Central South University of Forestry and Technology, Changsha 410004, Hunan, China
}

\begin{abstract}
Cotton fiber, one of main nature textile and longest single cell, is a good material for researching the cotton fiber development. In this study, fuzz mutant (FZ) and wild-type $(f z)$ which belong to diploid Gossypium arboreum species were used for unraveling molecular mechanism of fuzz fiber initiation by scanning electron microscopy (SEM), paraffin section and RNA sequencing technology. It was found that any fibers scarcely initiated on the ovule surface of the mutant at 0DPA, compared with that of the wild-type. Only lint fiber cells emerged on the ovule surface of fuzz mutant, while abundant fuzz and lint fiber cells appeared in wild-type at $+3 \mathrm{DPA}$ stage. The transcriptome analysis of $\mathrm{FZ}$ and $f z$ across the four fiber development stages (0DPA, $+3 \mathrm{DPA},+5 \mathrm{DPA}$, and +8DPA) indicated that the number of differentially expressed gene was 3780 . There were litter differentially expressed genes at 0DPA in FZ and $f z$. In the proceed of ovule development, the number of differentially expressed genes was increased gradually. The KEGG enriched pathway analysis illustrated that these differentially expressed genes were involved in cutin, suberine and wax biosynthesis, phenylalanine metabolism pathways and plant hormone signal transduction pathways. The analysis of co-expressed gene trend lines indicated that the up-regulated genes in mutant at +3DPA were all involved in metal ion binding, MAPK cascade, oxidoreductase activity and transcription regulation, resulting in failed fuzz fiber cells initiation in mutant. These findings elaborated a dynamic variation about fuzz fiber initiation in diploid G. arboreum, which provides a reference
\end{abstract}

本研究由国家自然科学基金项目(31601353)和国家重点研发计划项目(2017YFD0101601-03)资助。

This study was supported by the National Natural Science Foundation of China (31601353) and the National Key Technology R\&D Program (2017YFD0101601-03).

*通信作者(Corresponding authors): 杜雄明, E-mail: dxm630723@163.com; 龚文芳, E-mail: gwf018@126.com

第一作者联系方式: E-mail: wangxiaoyang198806@126.com

Received (收稿日期): 2019-09-02; Accepted (接受日期): 2019-12-26; Published online (网络出版日期): 2020-01-15.

URL: http://kns.cnki.net/kcms/detail/11.1809.S.20200115.1132.018.html 
for further research in the cotton fiber development.

Keywords: Gossypium arboreum; fuzzless mutant; differentially expressed gene; co-expressed trend

棉花是一种重要的经济作物, 种子是棉籽油的 主要原料, 纤维更是一种重要的天然纺织资源。棉 花纤维是高等植物中最长的单细胞突起, 由棉花胚 珠表皮细胞产生。棉纤维的长度一般为 30 40 $\mathrm{mm}^{[1]}$ 。 棉花纤维根据形态可以分为长纤维和短线 2 种不同 的类型。具有重要经济价值的长纤维在开花前 0DPA (day post anthesis)发育, 经过快速伸长, 纤维素生物 合成和成熟, 最终形成成熟的长纤维, 通过轧花从 种皮上收获并用于纺织产品 ${ }^{[2-3]}$ 。短线纤维起始于 $+3 \sim$ $+5 \mathrm{DPA}$, 长度不到 $5 \mathrm{~mm}$, 轧花后不能从种皮上分离下 来, 紧紧附着于种皮上, 对种子传播起重要作用 ${ }^{[4]}$ 。 胚珠上短纤维细胞和长纤维细胞的共存现象长期以 来一直受到研究者的关注, 为研究植物细胞的分化 提供了独特的模式体系。

棉纤维的发育受一系列基因调控, 这些基因与 植物激素信号转导、细胞能量代谢、脂肪酸代谢、 次生代谢等途径有关。目前关于调控纤维发育的基 因和调控网络的信息还不太清楚。在棉花基因组测 序之前, 许多研究者主要通过基因芯片技术篮选与 棉花纤维发育有关的基因, 在分子水平上了解纤维 发育的机制。如 Shi 等 ${ }^{[5]}$ 通过 cDNAs 芯片分析技术 发现了 778 个 cDNAs 优先在发育的纤维中表达。同 年, Yang 等 ${ }^{[6]}$ 通过分析陆地棉及其光子突变体转录 组, 鉴定出了受激素诱导的转录因子 MIXTA、MYB5、 $G L 2$ 在纤维起始过程中高表达。随着棉花基因组测 序的完成, 逐步完善了大量的棉花转基因技术, 使 得通过转录组分析与纤维发育相关的基因与代谢通 路成为可能 ${ }^{[7-9]}$ 。鉴定出一些与纤维发育及调控细胞 壁沉积与强度的候选基因 ${ }^{[10]}$ 。通过分析 $0 \mathrm{DPA}$ 和 +10DPA 的二倍体亚洲棉近等基因系有短线无长纤 维材料 $(F l)$ 和既有短线又有长纤维材料(FL)的转录 组发现, 一些参与植物激素信号转导、细胞能量代 谢, 脂肪酸代谢、刺激代谢的转录因子如 $A P 2$ EREBP、AUX/IAA、bHLH、C2H2、C3H、HB、MYB、 $N A C 、 O r p h a n s 、 P L A T Z$ 和 $W R K Y$ 在长纤维突变体+ 10DPA 纤维中明显下调, 植物受体样激酶 (plant receptor-like kinases, RLKs)、富含亮氨酸(Leucine Rich Repeats)的 LRR 家族蛋白和参与信号转导的编 码丝裂原活化蛋白激酶 (mitogen-activated protein kinase, MAPK)在突变体中也下调, 导致纤维生长减 慢 ${ }^{[11]}$ 。
虽然上述转录组分析的研究为棉纤维的起始过 程提供了一些研究基础, 但纤维发育的关键基因的 研究仍处于初级阶段, 长纤维和短线纤维发育及生 理过程仍然不清楚, 并且目前这些转录组研究主要 集中在纤维伸长阶段, 关于短线纤维起始的动态过 程研究较少。

突变体特有的性状是研究基因表达的有利资源, 分析植物突变体加速了特定基因功能的发现。本研 究所用的材料为二倍体亚洲棉短线突变体 GA0149 有长纤维没有短线(其光籽性状受单基因显性控制, 基因型为 $\mathrm{FZ}$ )及其野生型 GA0146 既有长纤维又有 短线(基因型为 $f z$ ), 经过连续十代的自花授粉, 突变 体植株光䊏性状稳定, 突变体和野生型材料在形态 和发育上区别微乎其微, 除了光籽突变体种皮上没 有短线 ${ }^{[8]}$ 。利用转录组测序技术分析突变体和野生 型 0DPA、+3DPA、+5DPA 和+8DPA 4 个时期的差异 基因表达情况, 旨在探究棉花短线起始的动态过程 及其关键基因, 为棉花短线起始的分子机制提供坚 实基础。

\section{1 材料与方法}

\section{1 试验材料}

亚洲棉野生型毛子材料为中美棉 DPL971 $(f z)$, 短线突变体材料为中美棉 DPL972 (FZ), 均来自棉 花种质资源中期库近 10 年的自交材料。2017 年在 中国农业科学院棉花研究所实验基地, 用标准的田 间管理措施, 按 3 个重复种植每个材料。

\section{2 扫描电镜}

将 2 个材料 $(f z$ 和 FZ) $0 \mathrm{DPA}$ 、 $+3 \mathrm{DPA}$ 的胚珠固定 于含有 $2.5 \%$ 戊二醛的 $0.1 \mathrm{~mol} \mathrm{~L}^{-1}$ 磷酸缓冲液中, 用真 空洜抽真空 $15 \mathrm{~min}$, 使胚珠完全浸没于固定液中, $4^{\circ} \mathrm{C}$ 过夜后用 $0.1 \mathrm{~mol} \mathrm{~L}^{-1} \mathrm{pH} 7.2$ 磷酸缓冲液洗 3 次, 每次 $10 \mathrm{~min}$; 接着, 用 $\mathrm{ddH}_{2} \mathrm{O}$ 清洗 2 次, 每次 $30 \mathrm{~min}$; 用 $30 \%(\mathrm{v} / \mathrm{v}) 、 50 \%(\mathrm{v} / \mathrm{v}) 、 70 \%(\mathrm{v} / \mathrm{v}) 、 80 \%(\mathrm{v} / \mathrm{v}) 、 95 \%(\mathrm{v} / \mathrm{v})$ 乙醇对样品梯度脱水, 每个梯度脱水 $20 \mathrm{~min}$; 用无 水乙醇对样品进行 3 次脱水; 再用等体积的乙醇: 乙酸异戊酯置换 $15 \mathrm{~min}$; 最后用 $100 \%$ 的乙酸异戊 酯置换 $15 \mathrm{~min}$; 将样品放于样品笼中用 $\mathrm{CO}_{2}$ 干燥, 然后喷金，用 JSM-6390/LV 扫描电镜观察。

\section{3 石蜡切片}

将新鲜的 $0 \mathrm{DPA} 、+3 \mathrm{DPA}$ 的胚珠固定于含有 $4 \%$ 
的 FAA (甲醛-冰乙酸-无水乙醇)固定液中, 抽真空, 保存于 $4{ }^{\circ} \mathrm{C}$ 冰箱中过夜, 用系列梯度浓度的乙醇 $(50 \% 、 70 \% 、 85 \% 、 95 \%$ 和 100\%)对样品进行脱水处 理, 每梯度 $30 \mathrm{~min}$; 将脱水处理过的胚珠包埋于处 理过的石蜡(Sigma-Aldrich)中, $60^{\circ} \mathrm{C}$ 透蜡 $2 \mathrm{~h}$; 然后 将胚珠放于预热的包埋框中, 迅速倒入融化的石蜡, 过夜使石蜡凝固。用石蜡切片机, 切成 $8 \mu \mathrm{m}$ 厚的连 续切片, 移至 $42^{\circ} \mathrm{C}$ 的水浴中, 使样品展平, 将切片 放在载玻片上, $37^{\circ} \mathrm{C}$ 干燥过夜。用番红固绿染色，用 带有数码相机的显微镜照相。

\section{4 文库构建与转录组测序}

用北京天根公司的多糖多酚植物总 RNA 试剂 盒提取 $\mathrm{FZ}$ 和 $f z 0 \mathrm{DPA}$ 、 $+3 \mathrm{DPA}$ 和 $+5 \mathrm{DPA}$ 的胚珠及 $+8 \mathrm{DPA}$ 的纤维的 RNA。将检测质量合格的 RNA 送 至北京百迈客生物公司进行 cDNA 文库的构建, 借 助 Illumina HiSeq 2000 测序仪进行双末端测序, 获 得原始数据。

\section{5 转录组原始数据的评估以及分析}

将得到的原始数据转化为 FASTQ 形式进行保存, 通过 fastp 软件过滤掉低质量数据和接头序列, 得到高 质量的 reads, 即 clean data.利用 TopHat2/Bowtie2 软件 将 clean reads 比对到亚洲棉三代基因组上 ${ }^{[8,12-13]}$ 。同 时对比对到参考基因组的序列进行注释，在比对过 程中, 每个错配最多允许 2 个碱基。采用 FPKM 值 (Fragments Per Kilobase of transcript per Million fragments mapped)来衡量基因表达 ${ }^{[13]}$ 。根据 FPKM 值, 以错误发现率 FDR $<0.01, \mid \log _{2}$ fold change $\mid \geq 1$, $P$-value $<0.01$ 作为篎选突变体和野生型差异表达基 因的标准。将获得的差异基因进行 GO 功能富集分 析(WEGO: http://wego.genomics.org.cn/cgi-bin/wego/ index.pl)和 KEGG 生物通路分析 ${ }^{[14-15]}$ 。

\section{6 苂光定量 Q-PCR 验证}

通过分析RNA-seq数据, 验证转录组数据的准确 性, 随机挑选22个差异表达的基因, 利用qRT-PCR进 行验证。利用在线软件NCBI-Primer (http://www.ncbi. nlm.nih.gov/tools/primer-blast/)设计引物(表1)。分别取 不同组织样品的总RNA $1 \mu \mathrm{g}$, 利用cDNA反转录试剂 盒PrimeScript RT reagent Kit (Perfect real time TaKaRa 生物)合成cDNA。利用北京全世金生物公司苂光定量 试剂盒(TransStart Top Green qPCR SuperMix), 以UBQ 作为内参基因, 利用 ABI7500fast Real-time PCR System (美国, ABI公司)开展苂光定量PCR验证。每
个基因设计 3 次技术重复和 3 次生物学重复。以 $f z$ 材料 0DPA样品的基因表达量作为 1 , 分析突变体和野生 型各个时期的基因相对表达量, 按 $2^{-\Delta \Delta \mathrm{CT}}$ 法计算相 对表达量 ${ }^{[16]}$ 。

\section{2 结果与分析}

\section{1 二倍体亚洲棉短线纤维起始的动态学观察}

前人研究结果表明, 长纤维细胞起始于开花当 天(0DPA), 在纤维发育早期阶段如在 +3 DPA时, 长 纤维已经突破表皮细胞, 长度约为 $2 \mathrm{~mm}$, 而短纤维 细胞还未突破表皮, 但是胚珠表皮细胞开始出现排 列不规则现象。为了鉴定野生型毛子 $f z$ 和突变体 $F Z$ 短线纤维起始的差异, 取这 2 个材料的 0 和 $+3 \mathrm{DPA}$ 的 胚珠, 用扫描电镜观察发现, 在0DPA时野生型和突 变体都有明显的纤维突起, 但是野生型纤维明显长 于突变体, 而且纤维数目多于突变体; 当胚珠发育 到 $+3 \mathrm{DPA}$ 时, $f z$ 和 $\mathrm{FZ}$ 长纤维长度基本一致, 但纤维数 目 $f z$ 多于FZ, 由于胚珠表面长纤维的干扰, 无法观 察到胚珠表面的短纤维(图 1-A)。为了进一步验证短 线在细胞水平上的突起, 在电子显微镜下观察 $f z$ 和 FZ 0DPA和+3DPA的胚珠的石蜡切片, 如图 1-B所示, 在野生型 $f z$ 胚珠表面能观察到长纤维和短纤维细 胞, 其中红色箭头所指位置为长纤维, 而黑色箭头 所指位置为短纤维细胞。在0DPA 时野生型纤维细胞 开始隆起, 而突变体只有少量突起; 随着胚珠的发 育 $f z$ 和 $\mathrm{FZ}$ 突起细胞数目都有所增加, 但是在 $+3 \mathrm{DPA}$ 时, 短线纤维开始在 $f z$ 胚珠表面出现, 而 $\mathrm{FZ}$ 胚珠在相同的发育阶段没有短线细胞突起，表 明短纤维细胞在FZ中起始失败。

\section{2 转录组数据质量评估}

为了进一步理解短线发育的动态过程和鉴定与 短线发育相关的基因, 选取突变体FZ和野生型材料 $f z 4$ 个发育时期的胚珠和纤维(0DPA、+3DPA、 +5 DPA、+8DPA)的RNA, 每个材料 3 个生物学重复, 构 建了24个RNA文库。

24 个测序文库获得的约 3.2 亿条原始数据经去 接头和过滤后, 产生出约1.6亿条clean reads。每个文 库平均得到65,841,318 个高质量的reads (表2)。大约 有 $88 \%$ 的clean reads可成功比对到已发表的亚洲棉 三代基因组上。比对到参考基因组上唯一位置和多 个位置的比例分别约为 $76 \% \sim 85 \% 、 3.53 \% \sim 6.00 \%$ 。 比对到基因组正链的数目与比对到负链的数目几乎 


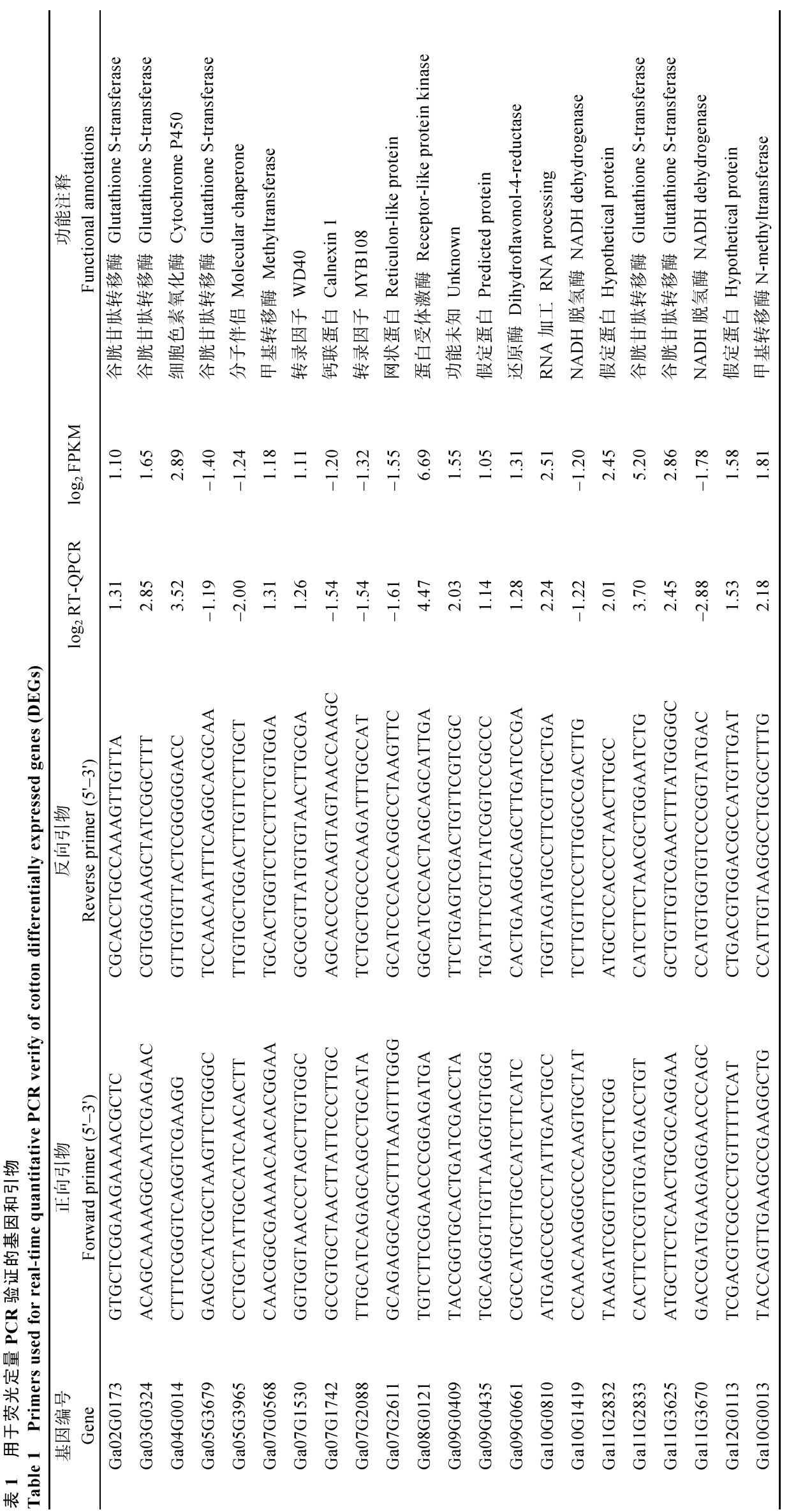




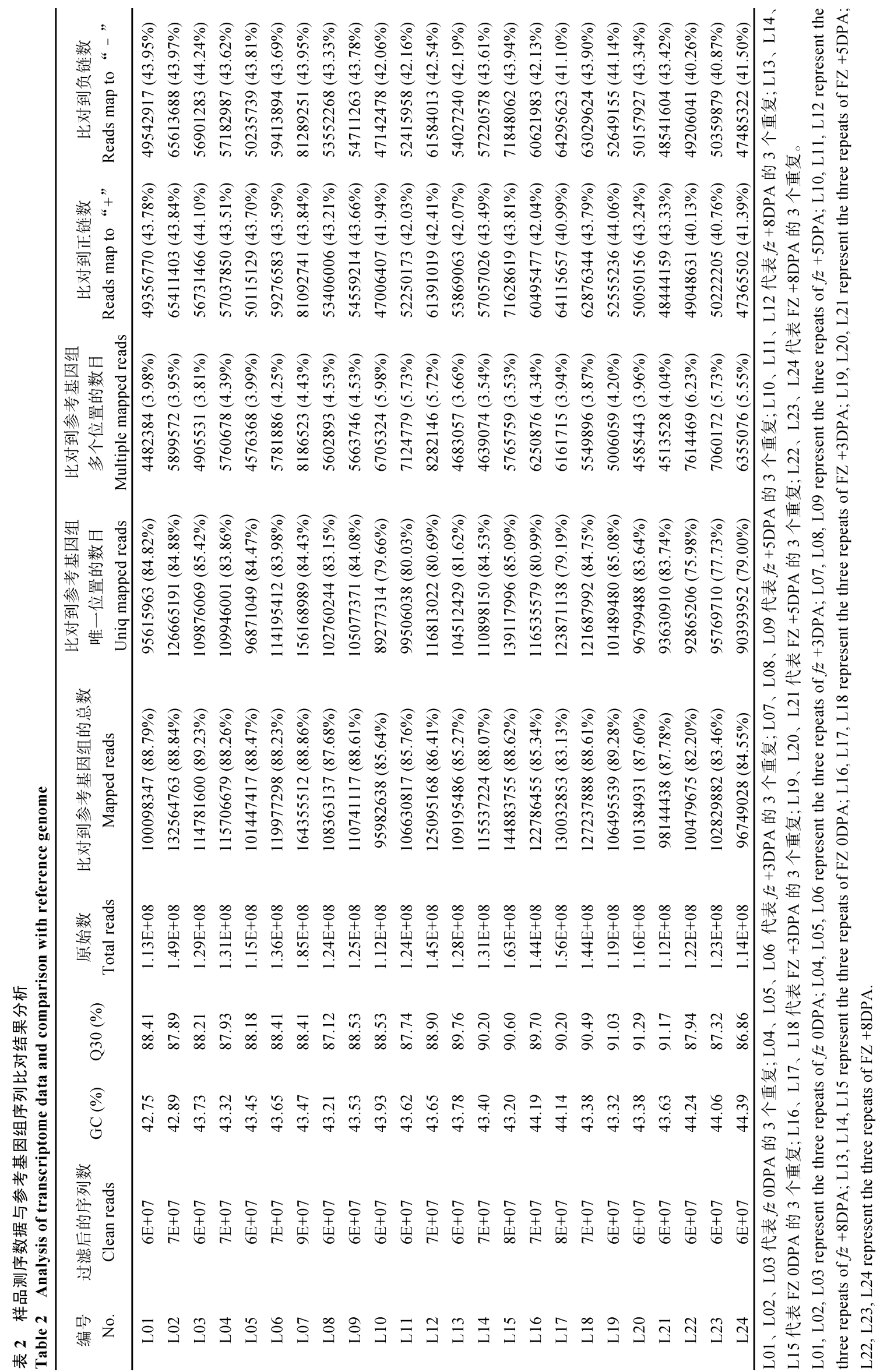



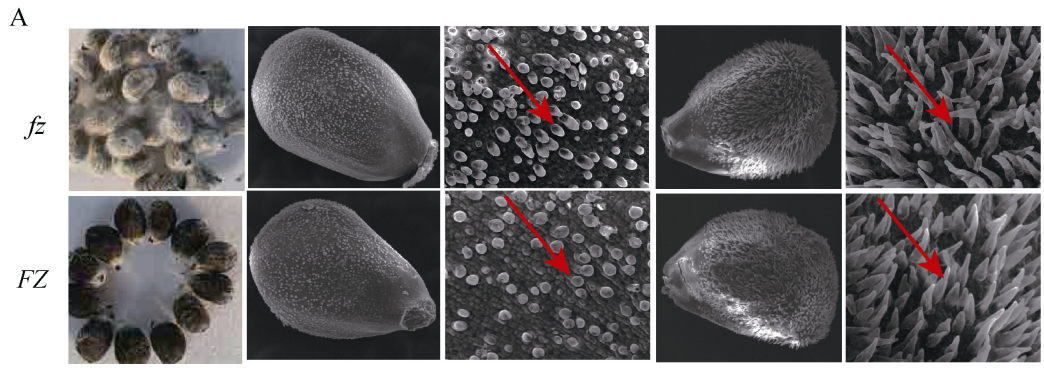

Seeds

ODPA

$+3 \mathrm{DPA}$

B

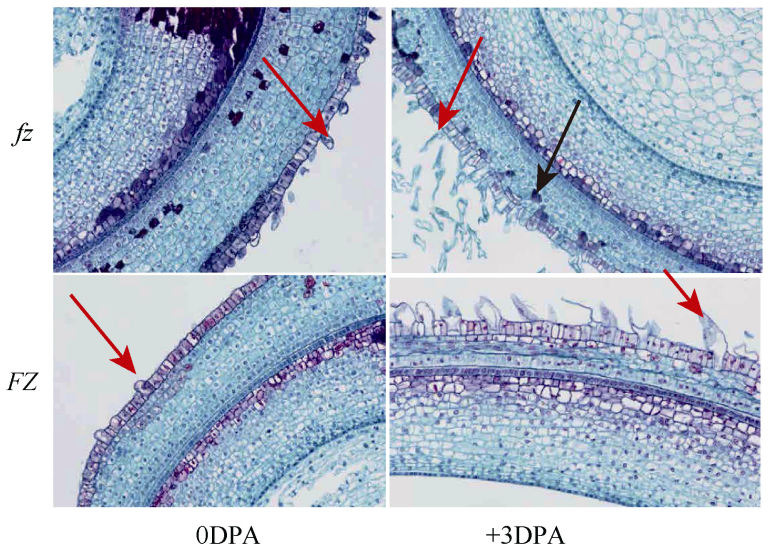

图 1 野生型 $f z$ 和短线突变体 $\mathrm{FZ}$ 材料中短纤维发育过程的形态学观察

Fig. 1 Morphology analysis of fuzz-fiber development in normal wilt-type $f z$ (upper) and fuzz mutant FZ (lower)

A: 野生型、短线突变体的种子以及扫描电镜下看到的短线纤维起始; B: 石蜡切片所示短线纤维起始。红色箭头所示长纤维, 黑色箭 头所示短纤维细胞。

A: the seeds of wild type, natural fuzz mutant and fuzz fiber initiation under scanning electron microscope; B: paraffin section showing fuzz fiber initiation. Red arrow indicates lint fiber, and black arrow indicates fuzz fiber cells.

A

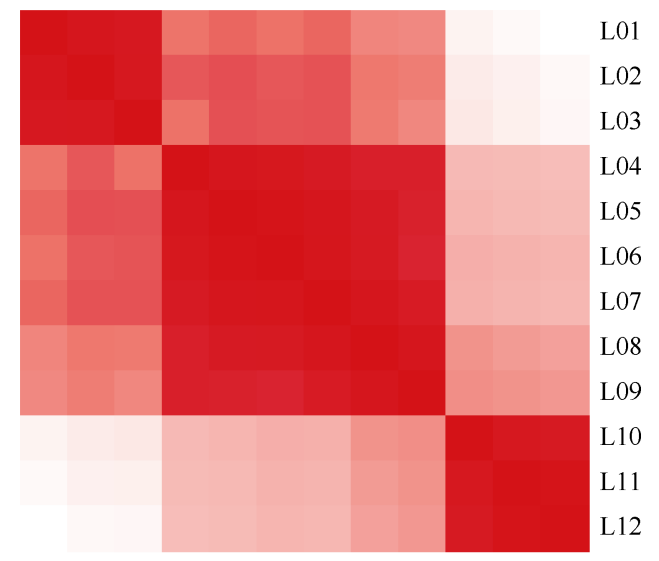

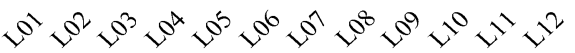

$R^{2}$

1.10

1.00

0.90

0.80

0.70

0.60

0.50

图 2 所有样本间皮尔逊相关系数分析

Fig. 2 Pearson correlation coefficients of all samples

$\mathrm{A}$ 和 $\mathrm{B}$ 分别代表 $f z$ 和 $\mathrm{FZ}$ 。 $\mathrm{A}$ and B indicate $f z$ and $\mathrm{FZ}$, respectively.

相当。另外每个样本的Q 30 比例均大于 $86 \%, \mathrm{GC}$ 含量 在 $35 \%$ 65\%衡量指标之间。

为了鉴定 24 个样品间的生物学重复关系, 对各 样本间生物学重复数据进行皮尔逊相关系数
B

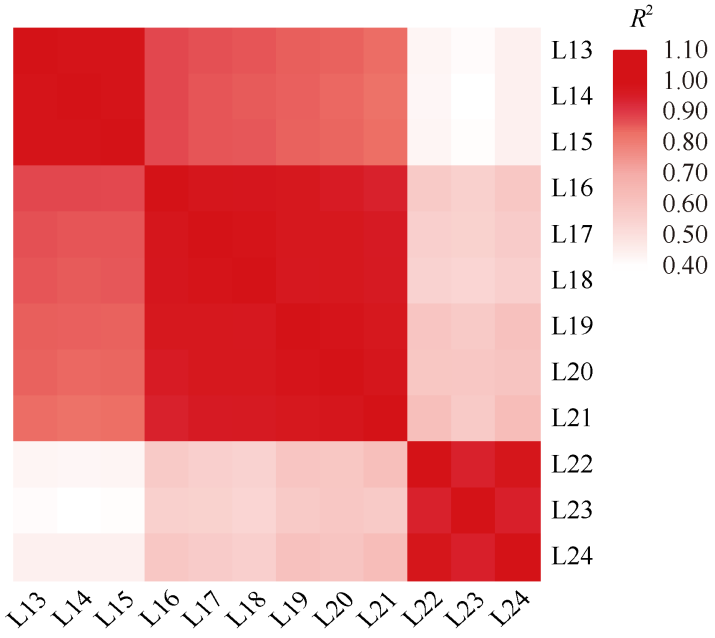

(Pearson Correlation Coefficient, PCC)分析(图2), 结 果发现, $f z$ 材料 3 个生物学重复间的皮尔逊相关系数 均大于 0.98 (图2-A), FZ 材料3个生物学重复间的皮 尔逊相关系数均大于 0.94 (图2-B), 说明这 2 个材料 
不同样本的 3 个生物学重复较好, 可进行差异基因 表达分析。

\section{3 差异基因表达分析}

计算FPKM值后，选择 $P$-value $<0.05$ 和 $\mid \log _{2}$ (ratio) $\mid$ $\geq 1$ 作为篮选差异表达基因的标准。通过比较突变体 $\mathrm{FZ}$ 和野生型 $f z$ 材料 $0 、+3 、+5 、+8 \mathrm{DPA}$ 的FPKM值, 共 鉴定出 3784个差异基因(图3-A)。其中在 $f z$ vs. FZ 0DPA时期特异表达的基因有 201 个, $f z$ vs. FZ + 3DPA 时期特异表达的基因有 313 个, $f z$ vs. FZ $+5 \mathrm{DPA}$ 特异 表达的基因有1108个, $f z$ vs. FZ +8DPA时期特异表达 的基因有 1303 个。突变体和野生型 4 个纤维发育时期发 现91个共有的差异基因, 这些基因的差异表达情况见 图3-B和表3，52个基因明显上调,39个基因明显的下 调，对差异基因功能分析发现一些未知蛋白、转录因 子、乙烯受体和抗病基因都参与了短线纤维的发育。

通过比较同一材料不同纤维发育时期的差异基 因发现(图4-A)在 $f z$ 材料中, 开花当天至 $+3 \mathrm{DPA}$ 时共 有 2227个基因上调，1113个基因下调; +3DPA至 +5DPA时期，601个基因上调，194个基因下调; +5DPA至+8DPA时期 2993个基因上调，3703个基因 下调。+3DPA至 $+5 \mathrm{DPA}$ 时期差异基因数目较少。在 FZ材料中, 0到 $+3 \mathrm{DPA}$ 时期, 2420个基因发生了上调, 下调基因的数目是 1201 ; +3DPA到 +5 DPA时期，611 个基因上调, 753 个基因下调; +5DPA到 $+8 \mathrm{DPA}$ 时期,
5465个基因上调, 6686个基因下调。

比较突变体FZ和野生型 $f z$ 同一纤维时期的差异 基因(图4-A，B)表明，在开花当天与野生型材料相比, 突变体中 341 个基因上调，174 个基因下调; 在 +3DPA时, 突变体中 612 个基因上调, 下调基因数目 170; 在 $+5 \mathrm{DPA}$ 时期, 突变体中发生了 1018 个基因上 调, 下调基因数目为 802 个; 在 $+8 \mathrm{DPA}$ 时期, 1230 个 基因下调, 641个基因上调; 突变体中在短线起始期 上调基因的数目多于下调基因的数目, 这些结果证 明大部分基因负调控短线纤维的起始。

\section{4 与短线起始相关的差异基因 KEGG 通路分析}

通过对 2 个材料 4 个纤维发育时期的差异基因 KEGG (Kyoto Encyclopedia of Genes and Genomes) 通路富集分析(图4-C)发现, 40个基因参与到植物-病 原菌互作过程; 20 个基因参与到精氨酸和脯氨酸代 谢过程; 52个基因参与到内质网上蛋白加工过程; 30 个基因涉及到苯丙烷代谢过程；17个基因涉及到角 质、木质素和蜡质生物合成过程; 44个基因参与到苯 丙烷生物合成过程; 92个基因汇集到植物激素信号 传导过程。对KEGG途径富集因子较高的植物激素 信号传导途径中的苯丙烷生物合成途径和角质木质 素以及蜡质生物合成途径的差异基因进一步分析发 现(表4和表5), 26个差异基因与生长素响应以及生物 合成有关，与野生型 $(f z)$ 相比，突变体(FZ)大部分基

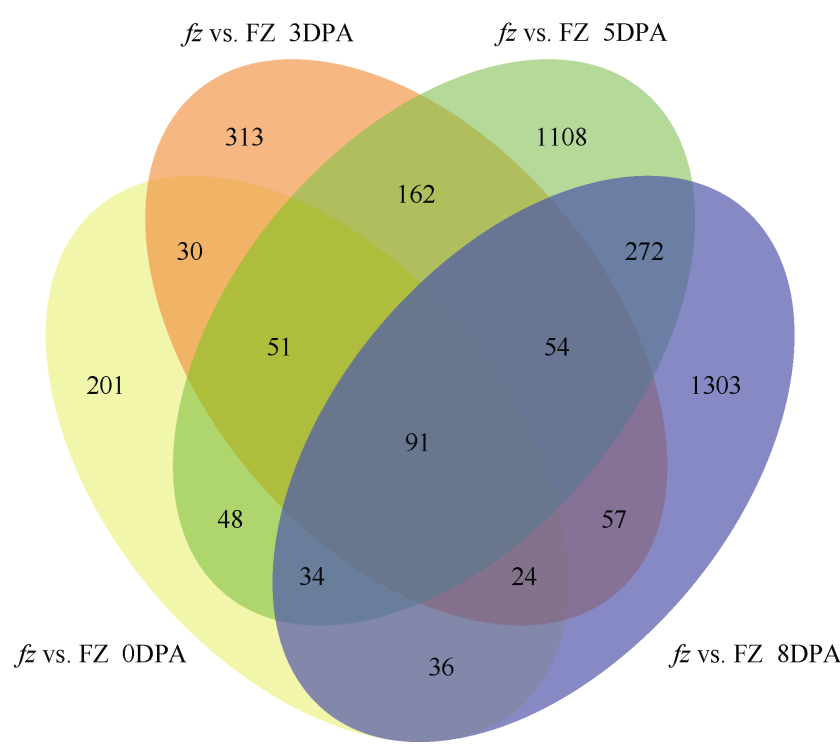

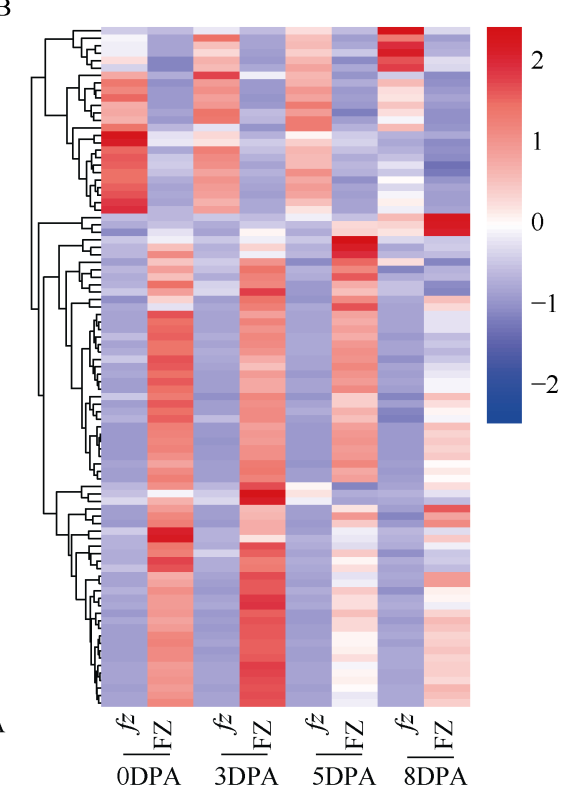

图 $3 f z$ 及其短线突变体 $\mathrm{FZ}$ 不同纤维发育时期共有的差异基因

Fig. 3 Common DEG at different fiber development stages in $f z$ and fuzz-mutant $F Z$

$\mathrm{A}$ : 在 $f z$ 和 $\mathrm{FZ}$ 材料中不同纤维发育时期差异基因韦恩图; B: 在 $f z$ 和 $\mathrm{FZ}$ 两个材料中 4 个纤维发育时期 91 个共有的差异基因热图。

A: Venn diagram of significant DEGs found in $f z$ and FZ across various fiber development stages; B: Heatmap showing 91 common significant DEGs in $f z$ and $\mathrm{FZ}$ across fiber development stages. 
A

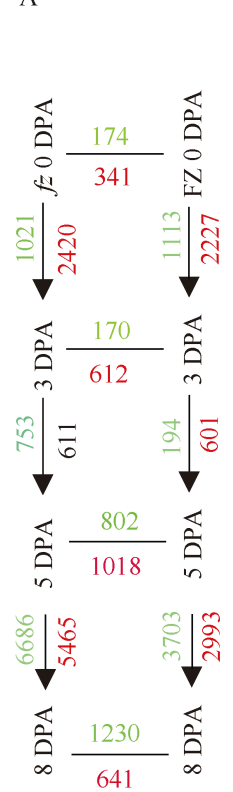

B

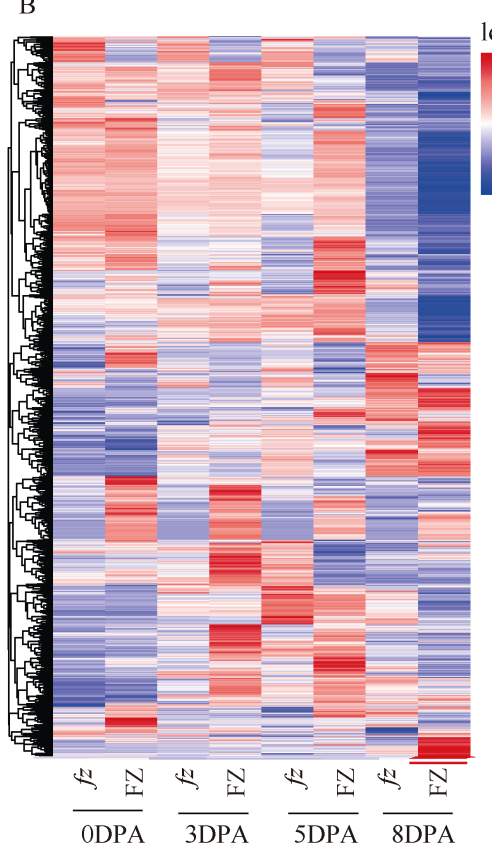

$\mathrm{C}$

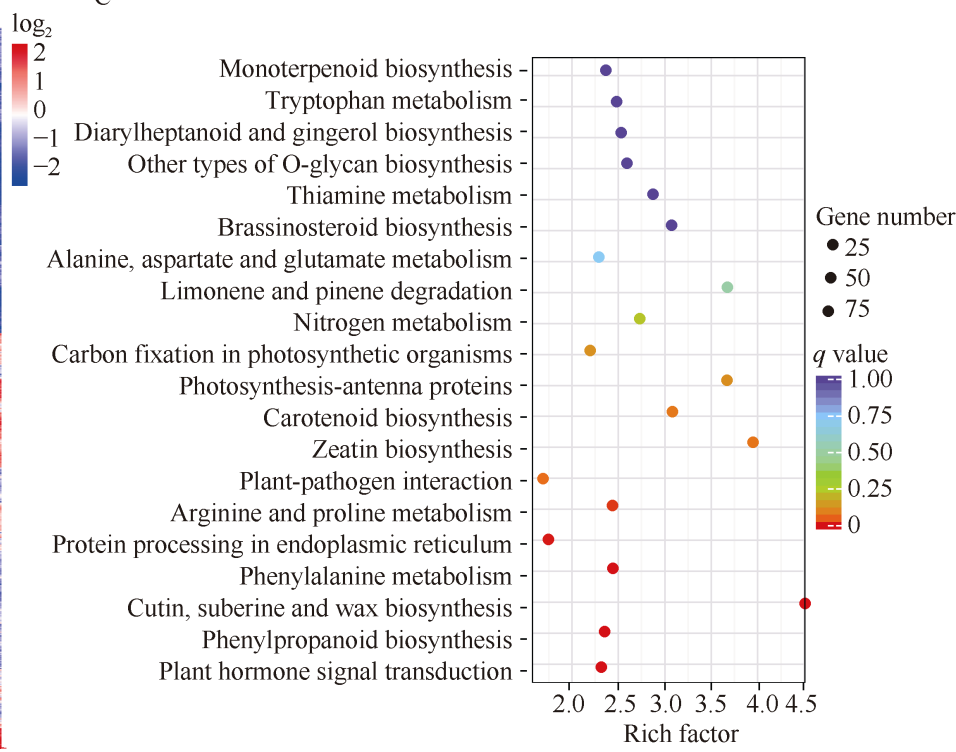

图 $4 f z$ 及其短线突变体 $\mathrm{FZ}$ 不同纤维发育时期差异基因概况

Fig. 4 Overview of DEGS at different fiber development stages in $f z$ and fuzz-mutant FZ

$\mathrm{A}$ : 在 $f z$ 和 $\mathrm{FZ}$ 材料中不同纤维发育时期差异基因数目; 红色代表上调的基因, 绿色代表下调基因。B: 1783 个差异基因在 $f z$ 和 $\mathrm{FZ}$ 材 料 4 个短线纤维发育时期的表达趋势。C: $f z$ 和 FZ 材料 4 个短线纤维发育时期差异基因 KEGG 富集通路。

A: number of genes differentially expressed during fiber development within and between $f z$ and FZ; Red represent up-regulated, green represent down-regulated gene. B: the expression trends of 1783 DEGs in $f z$ and FZ across fiber development stages; C: the DEGs KEGG pathway in $f z$ and $\mathrm{FZ}$ across fiber development stages.

\section{表 3 在 $f z$ 和 $\mathrm{FZ}$ 两个材料中 4 个纤维发育时期 91 个共有的差异基因及其表达情况}

Table 3 Ninety-one common significant DEGs found in $f z$ and FZ across fiber development stages and their expression

\begin{tabular}{|c|c|c|c|c|c|}
\hline 基因编号 Gene ID & 基因注释 Gene annotation & 0DPA & $+3 \mathrm{DPA}$ & $+5 \mathrm{DPA}$ & $+8 \mathrm{DPA}$ \\
\hline Ga11G2831 & 含有 WD40 结构的蛋白 WD40 repeat-like superfamily protein & 2.00 & 2.70 & 3.00 & 1.72 \\
\hline Cotton_newGene_517935 & 假定蛋白 Hypothetical protein & 2.55 & 2.94 & 1.88 & 1.84 \\
\hline Ga03G0324 & 谷胱甘肽 S-转移酶 Glutathione S-transferase & 1.33 & 1.65 & 1.63 & 1.05 \\
\hline Ga11G0115 & 假定蛋白 Hypothetical protein & -1.25 & -1.28 & -1.42 & -1.05 \\
\hline Ga07G1809 & 硫代硫酸盐 ATP 结合蛋白 Sulfate/thiosulfate ATP-binding protein & 2.35 & 2.34 & 2.40 & 0.95 \\
\hline Cotton_newGene_190500 & 末鉴定蛋白 Uncharacterized protein & 2.37 & 2.67 & 0.97 & 1.16 \\
\hline Cotton_newGene_217366 & 未鉴定蛋白 Uncharacterized protein & 2.03 & 2.44 & 1.33 & 1.65 \\
\hline Ga11G3311 & 葡萄糖基转移酶 UDP-glycosyltransferase $83 \mathrm{~A} 1$ & 1.25 & 1.98 & 1.50 & 1.85 \\
\hline Ga09G2202 & 乙烯响应因子 AP2/ERF & 1.95 & 1.31 & 2.13 & -1.42 \\
\hline Ga09G0608 & 亮氨酸拉链蛋白 Leucine-rich repeat protein kinase & -1.90 & -1.49 & -0.70 & -0.20 \\
\hline Cotton_newGene_190685 & 假定蛋白 Hypothetical protein & 1.39 & 1.60 & 0.94 & 0.89 \\
\hline Cotton_newGene_184413 & 假定蛋白 Hypothetical protein & 0.86 & 0.82 & 0.68 & 0.20 \\
\hline Cotton_newGene_216530 & 假定蛋白 Hypothetical protein & 1.42 & 1.92 & 0.70 & 1.48 \\
\hline Ga06G0475 & 泛素连接酶 E3 ligase & -0.74 & -0.80 & -0.53 & -0.61 \\
\hline Cotton_newGene_206595 & 假定蛋白 Hypothetical protein & 0.62 & 0.51 & 0.22 & 0.08 \\
\hline Cotton_newGene_188033 & 假定蛋白 Hypothetical protein & -3.18 & -2.89 & -2.89 & -1.50 \\
\hline Ga14G2119 & 谷氨酸受体 Glutamate receptor & 3.94 & 3.27 & 3.11 & 1.92 \\
\hline Cotton_newGene_206588 & 假定蛋白 Hypothetical protein & 2.13 & 2.00 & 1.73 & 0.92 \\
\hline Ga11G2832 & 自噬相关蛋白 Autophagy-related protein & 2.42 & 2.45 & 2.66 & 1.38 \\
\hline Ga06G1674 & 锌依赖的包外多肽酶蛋白 Zn-dependent exopeptidases protein & -1.22 & -0.78 & -0.75 & -0.57 \\
\hline
\end{tabular}


(续表 3)

\begin{tabular}{|c|c|c|c|c|c|}
\hline 基因编号 Gene ID & 基因注释 Gene annotation & 0DPA & $+3 \mathrm{DPA}$ & $+5 \mathrm{DPA}$ & $+8 \mathrm{DPA}$ \\
\hline Cotton_newGene_313214 & TMV 抗性蛋白 TMV resistance protein & 0.42 & 1.14 & 1.27 & 0.73 \\
\hline Ga04G1219 & 乙酰基葡萄糖转移酶 UDP-GlcNAc & 1.21 & 1.37 & 1.40 & 0.78 \\
\hline Cotton_newGene_383086 & ATP 合成酶 ATP synthase & 1.29 & 1.00 & 1.15 & 0.57 \\
\hline Cotton_newGene_336363 & 核酸内切酶 Endonuclease & 1.47 & 1.00 & 1.30 & 0.46 \\
\hline Cotton_newGene_521387 & 功能未知 Unknown & 1.87 & 1.81 & 1.73 & 1.36 \\
\hline Ga04G0915 & 功能未知 Unknown & 1.43 & 1.30 & 1.23 & 0.32 \\
\hline Cotton_newGene_190683 & 细胞色素氧化酶 P450 Cytochrome P450 & 2.78 & 3.25 & 2.09 & 1.73 \\
\hline Cotton_newGene_94861 & 核酸酶 Putative nuclease & -1.00 & -0.86 & -0.93 & -0.65 \\
\hline Cotton_newGene_195900 & 功能未知 Unknown & -3.47 & -3.50 & -3.45 & -2.85 \\
\hline Ga10G0013 & 甲基转移酶 Histone-lysine N-methyltransferase & 1.78 & 1.81 & 2.10 & 1.35 \\
\hline Ga11G0121 & 木糖梅 Alpha-xylosidase 1 & -1.64 & -0.77 & -0.92 & -1.26 \\
\hline Ga11G0187 & 假定蛋白 Hypothetical protein & -0.85 & -0.74 & -0.81 & -0.48 \\
\hline Ga11G0110 & 假定蛋白 Hypothetical protein & 0.82 & 1.21 & 0.71 & 0.84 \\
\hline Ga06G1755 & 脯氨酸受体蛋白激酶 Proline-rich receptor-like protein kinase & -1.00 & -0.52 & -0.98 & -0.95 \\
\hline Ga05G2954 & 天冬氨酸酶 Asparticase & 0.65 & 0.58 & 1.25 & 0.24 \\
\hline Cotton_newGene_572274 & 假定蛋白 Hypothetical protein & 2.24 & 2.62 & 1.48 & 1.69 \\
\hline Cotton_newGene_353692 & 假定蛋白 Hypothetical protein & -0.56 & -0.63 & -0.71 & -0.49 \\
\hline Cotton_newGene_483966 & 假定蛋白 Hypothetical protein & 2.77 & 2.77 & 2.71 & 2.30 \\
\hline Ga11G0111 & 微丝蛋白 $\mathrm{Fb} 17$ & -0.31 & -0.75 & -1.21 & -2.11 \\
\hline Cotton_newGene_99176 & 丝氨酸/苏氨酸蛋白磷酸酶 Serine/threonine protein phosphatase & 1.08 & 0.85 & 0.97 & 1.10 \\
\hline Ga12G1137 & 乙烯受体蛋白 AP2/ERF & 1.25 & 1.53 & 1.81 & -1.25 \\
\hline Ga11G2354 & 假定蛋白 Hypothetical protein & 1.73 & 1.58 & 1.68 & 0.31 \\
\hline Cotton_newGene_517938 & 细胞色素氧化酶 P450 Cytochrome P450 & 4.11 & 4.65 & 3.60 & 3.14 \\
\hline Cotton_newGene_300782 & 核酸内切酶亚基 Endonuclease subunit & 1.47 & 1.44 & 1.06 & 1.14 \\
\hline Cotton_newGene_252500 & Copia 型多蛋白 Copia-type polyprotein & 2.74 & 2.88 & 2.52 & 2.00 \\
\hline Cotton_newGene_517934 & 功能未知 Unknown & 3.19 & 3.84 & 2.65 & 1.73 \\
\hline Cotton_newGene_353671 & 缬氨酸-tRNA 连接酶 Valine-tRNA ligase & -0.39 & -0.95 & -0.65 & -0.94 \\
\hline Ga05G3965 & 功能未知 Unknown & -1.55 & -1.24 & -1.95 & -1.34 \\
\hline Ga09G1652 & 丝氨酸/苏氨酸蛋白磷酸酶 Serine/threonine protein phosphatase & -1.61 & -1.34 & -1.01 & -1.25 \\
\hline Ga04G1773 & 转录因子 NAC1 & 1.20 & 0.98 & 2.02 & -1.43 \\
\hline Ga09G1364 & 乙酰辅酶 A 氧化酶 Acyl-coenzyme A oxidase & 2.66 & 2.52 & 2.53 & 2.06 \\
\hline Cotton_newGene_213765 & 假定蛋白 Hypothetical protein & -1.28 & -1.29 & -1.89 & -1.22 \\
\hline Ga04G0280 & 富含脯氨酸蛋白 Proline-rich protein & 0.71 & 0.77 & 1.46 & 1.21 \\
\hline Cotton_newGene_217374 & 假定蛋白 Hypothetical protein & 1.56 & 1.89 & 0.72 & 1.26 \\
\hline Ga10G0798 & 细胞壁受体激酶 Wall-associated receptor kinase & 0.44 & 0.41 & 0.30 & 0.13 \\
\hline Ga03G0640 & 功能未知 Unknown & 1.88 & 1.62 & 1.14 & 1.16 \\
\hline Cotton_newGene_577041 & 功能未知 Unknown & 3.08 & 1.66 & 3.58 & 0.40 \\
\hline Ga07G1742 & 含有 CBS 结构域的蛋白 CBS domain-containing protein & -1.45 & -1.20 & -1.17 & -0.69 \\
\hline Ga07G2703 & 丝氨酸/苏氨酸蛋白磷酸酶 Serine/threonine-protein kinase & -0.81 & -0.59 & -0.39 & -0.26 \\
\hline Ga07G0566 & 转录因子 bHLH137 & 1.05 & 1.03 & 3.13 & -0.50 \\
\hline Cotton_newGene_190686 & 假定蛋白 Hypothetical protein & 1.42 & 1.61 & 0.84 & 0.86 \\
\hline Ga04G1342 & 未鉴定蛋白 Uncharacterized protein & 0.80 & 0.30 & 0.17 & 0.37 \\
\hline Cotton_newGene_563611 & 未鉴定蛋白 Uncharacterized protein & 2.35 & 2.52 & 1.44 & 1.83 \\
\hline Cotton_newGene_592029 & 丝裂原活化蛋白激酶 Mitogen-activated protein kinase MMK1 & -1.65 & -1.23 & -0.87 & -0.46 \\
\hline Ga01G1687 & 富含半胱氨酸/组氨酸蛋白 Cysteine/histidine-rich protein & 0.74 & 0.58 & 0.54 & 0.48 \\
\hline
\end{tabular}


(续表 3)

\begin{tabular}{|c|c|c|c|c|c|}
\hline 基因编号 Gene ID & 基因注释 Gene annotation & 0DPA & $+3 \mathrm{DPA}$ & $+5 \mathrm{DPA}$ & $+8 \mathrm{DPA}$ \\
\hline Cotton_newGene_54250 & 功能未知 Unknown & 2.88 & 2.87 & 2.67 & 1.88 \\
\hline Cotton_newGene_353710 & 假定蛋白 Hypothetical protein & 1.50 & 1.25 & 1.10 & 1.44 \\
\hline Cotton_newGene_474685 & 未鉴定蛋白 Uncharacterized protein & 2.45 & 2.75 & 1.40 & 1.79 \\
\hline Cotton_newGene_67170 & 假定蛋白 Hypothetical protein & 3.06 & 2.61 & 2.59 & 1.44 \\
\hline Cotton_newGene_353674 & 芳香类多肽 Pentafunctional arom polypeptide & 1.41 & 1.31 & 1.33 & 1.02 \\
\hline Ga03G1055 & 木聚糖糖基化酶 Xyloglucan endotransglucosylase & 0.83 & 2.34 & -1.71 & 0.96 \\
\hline Ga11G0123 & 甲硫氨酸 tRNA 转移酶 Methionine-tRNA ligase & -2.16 & -1.98 & -1.73 & -1.21 \\
\hline $\mathrm{Ga} 07 \mathrm{G} 0272$ & 咖啡酸盐酯酶 Caffeoylshikimate esterase & -1.59 & -1.52 & -1.82 & -1.20 \\
\hline Cotton_newGene_57872 & 假定蛋白 Hypothetical protein & 0.51 & 0.71 & 0.36 & 0.36 \\
\hline $\mathrm{Ga} 03 \mathrm{G} 2383$ & 受体蛋白 Receptor & -0.81 & -1.43 & -2.23 & 1.21 \\
\hline $\mathrm{Ga} 02 \mathrm{G} 0173$ & 假定蛋白 Hypothetical protein & 1.44 & 1.10 & 1.19 & 1.04 \\
\hline Cotton_newGene_509534 & 假定蛋白 Hypothetical protein & 1.82 & 2.28 & 1.03 & 1.35 \\
\hline Ga11G0124 & 未鉴定蛋白 Uncharacterized protein & -2.92 & -4.04 & -3.64 & -3.84 \\
\hline Ga13G1311 & 丝氨酸/苏氨酸蛋白磷酸酶 Serine/threonine-protein phosphatase & 1.80 & 1.60 & 1.61 & 1.42 \\
\hline Ga10G1419 & NADH 脱氢酶 NADH dehydrogenase & -0.99 & -1.20 & -1.37 & -1.31 \\
\hline Cotton_newGene_190499 & 未鉴定蛋白 Uncharacterized protein & 1.30 & 1.60 & 0.80 & 0.91 \\
\hline Cotton_newGene_217363 & 假定蛋白 Hypothetical protein & 1.69 & 2.16 & 0.97 & 1.75 \\
\hline $\mathrm{Ga} 07 \mathrm{G} 2215$ & 未鉴定蛋白 Uncharacterized protein & 1.38 & 2.23 & -2.23 & 0.98 \\
\hline Ga11G2833 & 谷胱甘肽 S-转移酶 Glutathione S-transferase & 4.06 & 5.20 & 5.45 & 1.92 \\
\hline Cotton_newGene_473974 & 功能未知 Unknown & 1.76 & 1.56 & 1.46 & 0.69 \\
\hline $\mathrm{Ga} 07 \mathrm{G} 0353$ & 富含脯氨酸蛋白 Proline-rich protein & 1.48 & 1.61 & 1.06 & 0.36 \\
\hline Cotton_newGene_99000 & 假定蛋白 Hypothetical protein & 0.73 & 0.61 & 0.46 & 0.92 \\
\hline Ga07G1792 & CBL9 & -1.33 & -1.33 & -1.07 & -0.68 \\
\hline Cotton_newGene_190497 & 假定蛋白 Hypothetical protein & 2.55 & 2.89 & 2.28 & 1.86 \\
\hline Ga09G1540 & 蛋白 YLS9 YLS9 protein & 0.88 & 1.12 & -0.82 & 0.66 \\
\hline Ga09G1216 & 川芎嗪-3 Tetraspanin-3 & -1.02 & -1.53 & -0.94 & -2.15 \\
\hline
\end{tabular}

因在 $+5 \mathrm{DPA}$ 时上调, 在 $+8 \mathrm{DPA}$ 时下调, 在 $+3 \mathrm{DPA}$ 时 基因表达差异不明显, 表明生长素(IAA)对短线的起 始没有影响，对短线纤维的伸长起正调控作用; 12 个基因参与脱落酸(ABA)和乙烯信号转导过程, 如 乙烯响应因子和脱落酸受体, 这些基因在短线纤维 起始时期+5DPA突变体中显著上调, Ga11G2673基 因差异倍数达到 15 以上, 而这些基因在纤维伸长时 期+8DPA突变体中下调, 这些结果说明棉花体内过 量的ABA和乙烯抑制纤维的发育, 而少量的乙烯能 促进纤维伸长。参与角质、软木质、蜡质生物合成 途径的基因有 8 个, 主要是细胞色素氧化酶P450和 脂肪酸着化酶(表 4$)$; 参与苯丙烷代谢和生物合成途 径有关的基因有 23 个, 大部分为过氧化物酶以及 2 个苯丙氨酸裂合酶、3个甲基转移酶和 1 个花青素葡 萄糖基转移酶, 说明这些基因与短线纤维的起始和 发育有关。

\section{5 差异基因共表达趋势分析}

为了研究野生型 $(f z)$ 和短线突变体(FZ)的差异基 因在胚珠和纤维中的表达情况, 对 2 个材料 4 个纤维 发育时期的 3784个差异基因绘制时空表达模式图 (图5-A), 结果发现 3784 个基因在 2 个材料4个纤维发 育时期可以划分为9组(cluster), 同一组的基因有相 同的表达趋势。clusters 1 和 2 的基因在突变体(FZ)的 开花当天表达高, 主要参与应答胁迫反应以及能量 传递过程; clusters 4、5和7的基因在突变体的 $+3 \mathrm{DPA}$ 表达高, 主要参与转录调控和钲离子, 铁离子, 铜 离子的结合; clusters 6 和 8 的基因在突变体材料开 花后 $5 \mathrm{~d}$ 表达高, 也主要涉及转录调控, 钙离子, 铁 离子和铜离子的结合过程; clusters 3 和9的基因主要 在突变体 $+8 \mathrm{DPA}$ 表达高, 主要参与水解酶活性, 转 运活性, 核酸激活, 脂肪酸生物合成途径和ATP结 合过程(图5-B)。 
表 4 角质、软木质、蜡质生物合成途径以及苯丙烷代谢途径的差异基因及其表达情况

Table 4 DEGs functioning in cutin, suberine and wax biosynthesis, and phenylalanine metabolism pathways and their expression

\begin{tabular}{|c|c|c|c|c|c|c|}
\hline $\begin{array}{l}\text { 基因编号 } \\
\text { Gene ID }\end{array}$ & $\begin{array}{c}\text { 基因功能 } \\
\text { Gene function }\end{array}$ & 0DPA & $+3 \mathrm{DPA}$ & $+5 \mathrm{DPA}$ & $+8 \mathrm{DPA}$ & KEGG_pathway_annotation \\
\hline $\mathrm{Ga} 01 \mathrm{G} 2133$ & $\begin{array}{l}\omega \text {-羟基棕㭣酸酯-乙酰酰转移酶 } \\
\text { Omega-hydroxypalmitate-feruloyl transferase }\end{array}$ & 0.05 & 0.52 & -0.11 & 1.07 & Cutin, suberine, and wax biosynthesis \\
\hline $\mathrm{Ga} 12 \mathrm{G} 0500$ & 细胞色素氧化酶 P450 Cytochrome P450 & -0.06 & 0.18 & -1.22 & -1.24 & Cutin, suberine, and wax biosynthesis \\
\hline $\mathrm{Ga} 07 \mathrm{G} 2444$ & 细胞色素氧化酶 P450 Cytochrome P450 & 0.06 & 1.06 & -0.18 & -0.40 & Cutin, suberine, and wax biosynthesis \\
\hline Ga08G1573 & 细胞色素氧化酶 P450 Cytochrome P450 & -0.81 & -0.68 & -0.63 & 1.02 & Cutin, suberine, and wax biosynthesis \\
\hline Ga08G2220 & 细胞色素氧化酶 P450 Cytochrome P450 & -1.95 & -2.11 & -2.22 & 0.14 & Cutin, suberine, and wax biosynthesis \\
\hline Ga10G2228 & $\begin{array}{l}\omega \text {-羟基棕榈酸酯-乙酰酰转移酶 } \\
\text { Omega-hydroxypalmitate-feruloyl transferase }\end{array}$ & 0.59 & -1.55 & 0.32 & 0.59 & Cutin, suberine, and wax biosynthesis \\
\hline Ga04G1297 & 脂肪酸差化酶 Fatty acid hydroxylase & -0.95 & -0.15 & 0.31 & 2.10 & Cutin, suberine, and wax biosynthesis \\
\hline Ga07G2443 & 细胞色素氧化酶 P450 Cytochrome P450 & 0.05 & 1.16 & -0.09 & -0.37 & Cutin, suberine, and wax biosynthesis \\
\hline Ga05G2018 & 过氧化物酶 Peroxidase & 0.34 & 0.88 & 1.20 & -0.25 & Phenylalanine metabolism \\
\hline Ga14G0143 & $\begin{array}{l}\text { 肉桂醇脱氢酶 } \\
\text { Cinnamyl alcohol dehydrogenase }\end{array}$ & -0.06 & 0.47 & 0.77 & -1.41 & Phenylpropanoid biosynthesis \\
\hline Ga10G0561 & 甲基转移酶 Caffeic acid-methyltransferase & 0.08 & -0.02 & -0.19 & -1.30 & Phenylalanine metabolism \\
\hline Ga11G3625 & 过氧化物酶 Peroxidase & 0.65 & 2.86 & 1.37 & 1.11 & Phenylalanine metabolism \\
\hline Ga12G1737 & 甲基转移酶 Caffeic acid-methyltransferase & -1.18 & -0.54 & -0.96 & 1.15 & Phenylpropanoid biosynthesis \\
\hline Ga05G1817 & 过氧化物酶 Peroxidase & -0.05 & 0.33 & -0.17 & -2.71 & Phenylalanine metabolism \\
\hline Ga12G2843 & 过氧化物酶 Peroxidase & -1.71 & -1.17 & -0.29 & -0.02 & Phenylalanine metabolism \\
\hline Ga12G0336 & 甲基转移酶 Caffeic acid-methyltransferase & 0.35 & 0.44 & -0.05 & -1.12 & Phenylpropanoid biosynthesis \\
\hline Ga03G0366 & $\begin{array}{l}\text { 花青素葡萄糖基转移酶 } \\
\text { Anthocyanidin-glucosyltransferase }\end{array}$ & 0.25 & 0.72 & -0.22 & 1.45 & Phenylpropanoid biosynthesis \\
\hline Ga05G0239 & 乙烯脱氢酶 Aldehyde dehydrogenase & -0.01 & 0.02 & 0.37 & -3.41 & Phenylpropanoid biosynthesis \\
\hline Ga09G0681 & 葡萄糖苷酶 Glucosidase & -0.18 & 0.30 & -0.15 & -1.20 & Phenylpropanoid biosynthesis \\
\hline Ga04G1983 & 过氧化物酶 Peroxidase & 0.08 & 0.33 & 0.23 & -1.16 & Phenylalanine metabolism \\
\hline Ga09G1700 & $\begin{array}{l}\text { 苯丙氨酸氨裂合酶 } \\
\text { Phenylalanine ammonia-lyase }\end{array}$ & -0.19 & 0.37 & -1.21 & -0.84 & Phenylalanine metabolism \\
\hline $\mathrm{Ga} 01 \mathrm{G} 2475$ & 过氧化物酶 Peroxidase 68 & 0.42 & 2.69 & 0.60 & -0.49 & Phenylalanine metabolism \\
\hline Ga10G0968 & 肉桂酸 4-羟化酶 Cinnamate 4-hydroxylase & 0.24 & -0.26 & -1.28 & -0.01 & Phenylalanine metabolism \\
\hline Ga11G1671 & 过氧化物酶 Peroxidase 17 & 0.13 & 0.46 & 0.05 & -2.06 & Phenylalanine metabolism \\
\hline Ga10G1786 & 过氧化物酶 Cationic peroxidase 1 & 0.46 & 1.38 & 0.50 & -0.25 & Phenylalanine metabolism \\
\hline Ga10G1772 & $\begin{array}{l}\text { 莽草酸 O-羟基肉桂酰基转移酶 } \\
\text { Shikimate O-hydroxycinnamoyltransferase }\end{array}$ & 0.04 & 1.14 & 1.78 & 1.38 & Phenylpropanoid biosynthesis \\
\hline Ga11G2088 & 过氧化物酶 Peroxidase 72 & 0.42 & 0.22 & 0.79 & -2.38 & Phenylalanine metabolism \\
\hline Ga13G0640 & 细胞色素氧化酶 P450 Cytochrome P450 & -0.09 & 0.15 & 0.12 & -1.35 & Phenylpropanoid biosynthesis \\
\hline Ga12G1739 & $\begin{array}{l}\text { 氨基甲酸 N-甲基转移酶 } \\
\text { Anthranilate N-methyltransferase }\end{array}$ & -1.30 & -0.86 & -0.68 & 0.34 & Phenylpropanoid biosynthesis \\
\hline Ga04G0842 & $\begin{array}{l}\text { 苯丙氨酸裂解酶 } \\
\text { Phenylalanine ammonia-lyase }\end{array}$ & -0.12 & 0.06 & -1.08 & -0.88 & Phenylalanine metabolism \\
\hline Ga04G1242 & 过氧化物酶 Peroxidase 51 & 0.44 & 1.08 & -0.02 & 0.17 & Phenylalanine metabolism \\
\hline
\end{tabular}


表 5 植物激素转导途径中的差异基因及其表达情况

Table 5 DEGs in plant hormone signal transduction pathways and their expression

\begin{tabular}{|c|c|c|c|c|c|c|c|}
\hline $\begin{array}{l}\text { 基因编号 } \\
\text { Gene ID }\end{array}$ & $\begin{array}{c}\text { 基因注释 } \\
\text { Gene annotation }\end{array}$ & $\begin{array}{l}\text { 基因名称 } \\
\text { Gene name }\end{array}$ & $\begin{array}{c}\text { 激素 } \\
\text { Hormone }\end{array}$ & 0DPA & $+3 \mathrm{DPA}$ & $+5 \mathrm{DPA}$ & $+8 \mathrm{DPA}$ \\
\hline Ga06G1125 & 乙烯响应因子 EIN3-binding F-box protein 1 & EIN3 & ETH & 1.1 & 1.1 & 4.6 & 0.4 \\
\hline $\mathrm{Ga} 01 \mathrm{G} 1781$ & 生长素响应因子 Auxin response factor 9 & $A R F 9$ & IAA & 1.0 & 1.2 & 2.4 & 0.6 \\
\hline Ga09G2536 & 生长素诱导蛋白 Auxin-induced protein 22D & $A U X 22 D$ & IAA & 1.6 & 1.0 & 2.6 & 1.6 \\
\hline Ga02G1198 & 脱落酸不敏感蛋白 Abscisic acid-insensitive protein & $A B I 3$ & $\mathrm{ABA}$ & 0.7 & 0.8 & 2.1 & 0.4 \\
\hline Ga01G2735 & 转录因子 MYC4 Transcription factor MYC4 & $M Y C 4$ & JA & 1.7 & 1.4 & 4.1 & 0.5 \\
\hline Ga13G1098 & 生长素诱导蛋白 Auxin-induced protein X10A & $A I P 10 A$ & IAA & 1.0 & 1.0 & 0.6 & 2.2 \\
\hline Ga03G2153 & 吲哚乙酸合成酶 Indole-3-acetic acid-amido synthetase & $I A A$ & IAA & 0.9 & 5.0 & 2.7 & 0.6 \\
\hline $\mathrm{Ga} 05 \mathrm{G} 2728$ & 生长素诱导蛋白 Auxin-induced protein 6B & $A I P 6 B$ & IAA & 1.2 & 0.9 & 3.2 & 1.0 \\
\hline Ga11G1087 & 生长素响应蛋白 Auxin-responsive protein IAA16 & IAA16 & IAA & 0.8 & 1.1 & 4.2 & 0.4 \\
\hline $\mathrm{Ga} 07 \mathrm{G} 0242$ & 脱落酸受体 Abscisic acid receptor & $P Y L 2$ & $\mathrm{ABA}$ & 1.2 & 1.7 & 1.5 & 0.7 \\
\hline Ga01G0771 & 吲哚乙酸合成酶 Indole-3-acetic acid-amido synthetase & $I A A$ & IAA & 1.4 & 1.3 & 3.0 & 0.5 \\
\hline Ga08G2804 & 乙烯响应因子 Ein3-binding F-box protein 4 & EIN3 & ETR & 1.4 & 1.2 & 4.6 & 0.7 \\
\hline Ga06G2183 & 磷酸转移蛋白 Histidine-containing phosphotransfer protein 4 & $A H P 4$ & $\mathrm{CK}$ & 1.0 & 1.0 & 0.6 & 0.4 \\
\hline Ga10G2395 & 生长素响应蛋白 Auxin-responsive protein IAA26 & SRK2I & IAA & 0.8 & 1.4 & 2.3 & 0.7 \\
\hline Ga10G3077 & 生长素诱导蛋白 Auxin-induced protein X15 & AIPX15 & IAA & 0.3 & 0.4 & 0.7 & 1.0 \\
\hline Ga08G2252 & 生长素响应蛋白 Auxin-responsive protein IAA11 & IAA11 & IAA & 1.2 & 0.9 & 2.5 & 0.6 \\
\hline $\mathrm{Ga} 03 \mathrm{G} 2608$ & 生长素诱导蛋白 Auxin-induced protein X10A & $A I P 10 A$ & IAA & 2.2 & 0.8 & 1.3 & 1.0 \\
\hline $\mathrm{Ga} 03 \mathrm{G} 0428$ & 乙烯受体 Ethylene receptor 2 & ETR2 & ETH & 1.3 & 0.9 & 2.6 & 0.7 \\
\hline Ga11G1046 & 乙烯受体 Ethylene receptor & EIN4 & ETH & 1.3 & 1.2 & 2.2 & 0.8 \\
\hline $\mathrm{Ga} 07 \mathrm{G} 0142$ & 蛋白磷酸酶 Protein phosphatase $2 \mathrm{C}$ & $P P 2 C$ & $\mathrm{ABA}$ & 1.5 & 1.6 & 4.0 & 0.8 \\
\hline $\mathrm{Ga} 05 \mathrm{G} 0163$ & 乙烯响应蛋白 EIN3-binding F-box protein 1 & EIN3 & ETH & 0.9 & 1.2 & 3.6 & 0.4 \\
\hline Ga09G2537 & 生长素响应蛋白 Auxin-responsive protein IAA14 & IAA14 & IAA & 1.0 & 0.5 & 0.4 & 1.2 \\
\hline Ga12G2846 & 赤霉素受体 Gibberellin receptor GID1B & $G I D 1 B$ & GA & 1.2 & 1.8 & 2.1 & 0.4 \\
\hline Ga08G2885 & 蛋白磷酸酶 Protein phosphatase $2 \mathrm{C}$ & $P P 2 C 77$ & $\mathrm{ABA}$ & 1.4 & 1.3 & 3.9 & 0.4 \\
\hline $\mathrm{Ga} 07 \mathrm{G} 0455$ & 生长素响应蛋白 Auxin-responsive protein IAA9 & $I A A 9$ & IAA & 1.6 & 0.8 & 2.6 & 0.3 \\
\hline Ga03G2632 & 生长素转运蛋白 Auxin transporter-like protein 5 & ATP5 & IAA & 0.9 & 1.1 & 2.3 & 0.8 \\
\hline Ga11G3045 & 脱落酸受体 Abscisic acid receptor & PYL9 & $\mathrm{ABA}$ & 1.6 & 1.2 & 4.2 & 0.4 \\
\hline Ga11G1086 & 生长素诱导蛋白 Auxin-induced protein 22D & $A U X 22 D$ & IAA & 1.3 & 1.8 & 6.4 & 0.5 \\
\hline Ga03G2592 & 生长素诱导蛋白 Auxin-induced protein 15A & $A U X 15 A$ & IAA & 0.9 & 0.6 & 0.5 & 2.2 \\
\hline Ga05G1344 & 生长素响应蛋白 Auxin-responsive protein IAA16 & IAA16 & IAA & 1.5 & 1.0 & 2.3 & 0.6 \\
\hline Ga05G2981 & 细胞分裂素响应蛋白 Cytokinin ARR17 & ARR17 & IAA & 1.0 & 1.2 & 1.0 & 0.5 \\
\hline Ga11G2673 & 乙烯响应转录因子 Ethylene-responsive transcription factor & ERF10 & ETH & 1.8 & 1.0 & 15.7 & 0.1 \\
\hline Ga12G2331 & ABA 相关蛋白激酶 ABA-related protein kinase & SNF1 & $\mathrm{ABA}$ & 1.2 & 1.3 & 2.1 & 0.9 \\
\hline $\mathrm{Ga} 05 \mathrm{G} 0157$ & 生长素响应蛋白 IAA29 Auxin-responsive protein IAA29 & IAA29 & IAA & 1.3 & 0.8 & 0.5 & 0.5 \\
\hline $\mathrm{Ga} 02 \mathrm{G} 1269$ & 水杨酸相关蛋白 Salicylic acid-related protein & $P R P 1$ & SA & 0.8 & 0.9 & 0.4 & 0.5 \\
\hline Ga06G2185 & 磷酸转移蛋白 Histidine phosphotransfer protein & AHP3 & $\mathrm{CK}$ & 1.0 & 0.9 & 0.7 & 0.5 \\
\hline Ga13G2114 & 生长素诱导蛋白 Auxin-induced protein 22B & $A U X 15 A$ & IAA & 1.4 & 1.2 & 2.1 & 1.9 \\
\hline $\mathrm{Ga} 05 \mathrm{G} 3500$ & 生长素诱导蛋白 Auxin-induced protein X15 & $A U X 15$ & IAA & 3.6 & 0.7 & 0.9 & 0.6 \\
\hline $\mathrm{Ga} 07 \mathrm{G} 1535$ & 吲哚乙酸合成酶 Indole-3-acetic acid-amido synthetase & $I A A$ & IAA & 0.8 & 1.3 & 1.5 & 0.4 \\
\hline $\mathrm{Ga} 09 \mathrm{G} 2560$ & 乙烯受体 Ethylene receptor 2 & ETR2 & ETH & 1.3 & 1.4 & 6.3 & 0.3 \\
\hline $\mathrm{Ga} 03 \mathrm{G} 2582$ & 生长素诱导蛋白 Auxin-induced protein 15A & $A U X 15 A$ & IAA & 1.0 & 0.9 & 2.1 & 0.8 \\
\hline $\mathrm{Ga} 05 \mathrm{G} 1383$ & 生长素响应蛋白 Auxin-responsive protein IAA27 & IAA27 & IAA & 1.1 & 1.1 & 1.3 & 0.2 \\
\hline Ga11G1865 & 生长素响应蛋白 Auxin-responsive protein & $I A A$ & IAA & 1.3 & 0.9 & 2.0 & 0.4 \\
\hline $\mathrm{Ga} 05 \mathrm{G} 1988$ & 生长素诱导蛋白 Auxin-induced protein 6B & $A U X 6 B$ & IAA & 1.1 & 0.8 & 2.9 & 0.3 \\
\hline
\end{tabular}




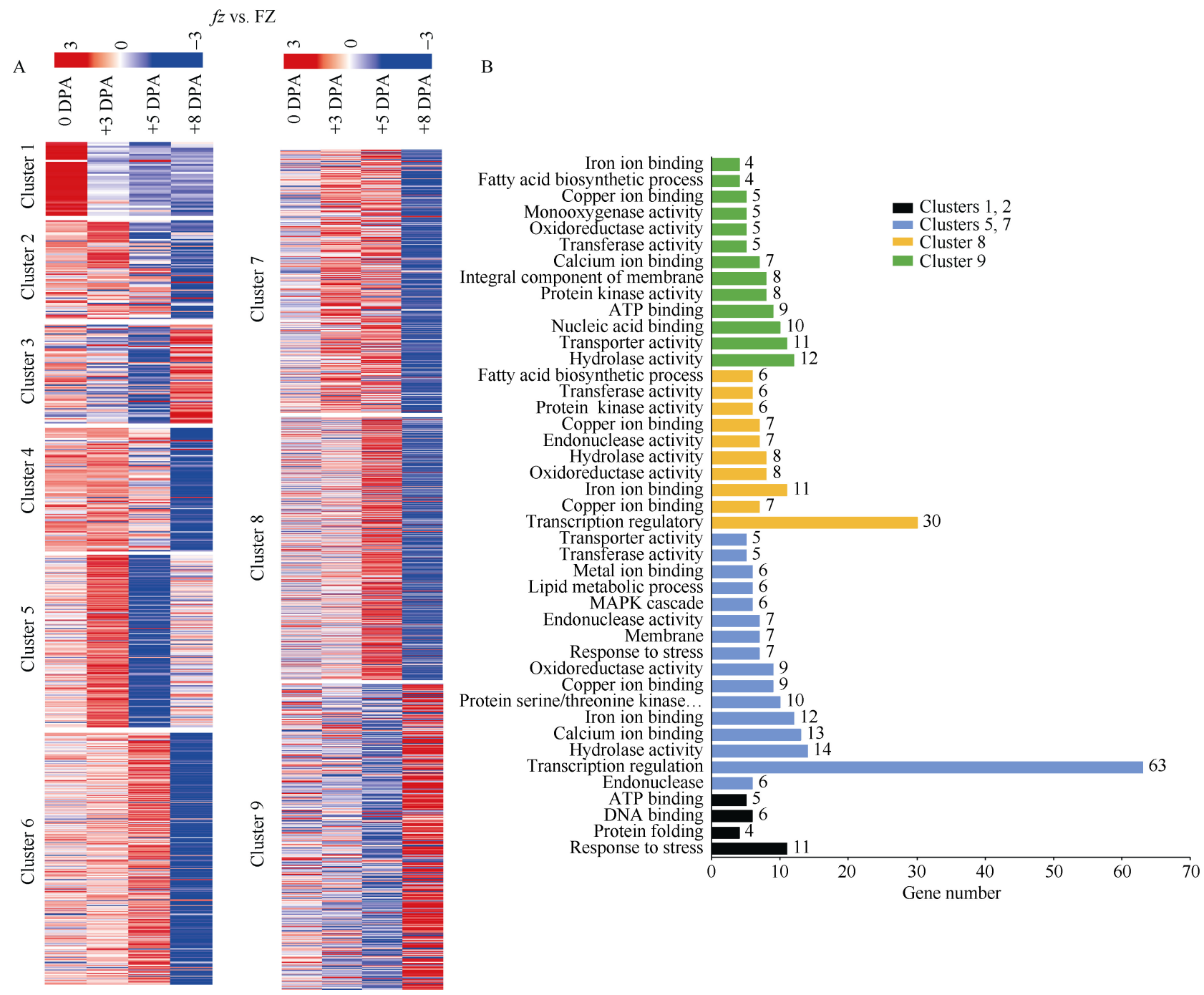

图 5 差异基因共表达趋势

Fig. 5 Coexpression analysis of all significant DEGs

$\mathbf{A}$ : 在 $f z$ 和 $\mathrm{FZ}$ 两个材料中 4 个纤维发育时期所有差异表达基因的热图分析。B: 差异基因功能注释; 黑色代表 0DPA 时期高表达的基 因, 蓝色代表+3DPA 时期高表达的基因, 橙色代表+5DPA 时期高表达的基因, 绿色代表+8DPA 时期高表达的基因。

A: heatmap analysis of the expression of all significant DEGs between $f z$ and FZ at four time points. B: functional annotations of significant DEGs; Black bars indicate genes highly expressed at 0DPA, blue bars indicate genes highly expressed at +3DPA, orange bars indicate genes highly expressed at $+5 \mathrm{DPA}$, and green bars indicate genes highly expressed at $+8 \mathrm{DPA}$.

\section{6 陆地棉控制短线基因在亚洲棉短线突变体}

FZ 及其野生型 $f z$ 的表达分析

前人通过图位克隆，在四倍体陆地棉中分别定 位出了一个控制短线发育和长纤维发育的基因, 即 MYBMIXTA-like 转 录 因子 GhMML3_A12 和 GhMML4_D12;GhMML3_A12在TM-1短线起始期表 达量明显高于其在短线突变体 $N 1$ 中的表达量; GhMML4_D12在仅有长纤维的短线突变体 $n 2 N S M$ 纤 维起始期的表达量明显高于其在陆无絮XZ142FLM 中的表达量 ${ }^{[17-18]}$ 。为了验证 GhMML3_A12 和 GhMML4_D12在亚洲棉短线突变体FZ和其野生型 $f z$ 中的表达量, 将这 2 个基因的蛋白序列在亚洲棉中
进行同源性比对 (图 6) 表明, GhMML3_A12 和 GhMML4_D12在亚洲棉中为同一个基因 Ga12G1199, 基因功能注释显示该基因属于MYB类转录因子，其 相似性达到 $97 \%$ 。转录组数据分析表明, Ga12G1199 在FZ材料短线起始期表达量高于其在 $f z$ 材料中的表 达量(图7), 说明Ga12G1199可能负调控短线发育。

\section{7 差异基因实时菼光定量 PCR 验证}

为了验证转录组数据的可靠性, 随机选择 22 个 差异基因在 2 个材料 $+3 \mathrm{DPA}$ 胚珠中进行苂光定量 PCR验证。结果显示, RNA-seq结果与苂光定量PCR 中的基因表达变化一致。通过单样本 $t$ 检验, 野生型 $f z+3 \mathrm{DPA}$ 胚珠中 22 个差异基因表达量与突变体FZ胚 
Ga12G1 199.1 MQQS P CS DKVGL KKGP WTPEEDQKLLS YI QEHGGGS URGLP AKAGLQRCGKS CRLR WI NYLRPDI KRGKF S S QEERTI I Q 80 GhMML3_A12 MQQS P CS DKVGLKKGP WTPEEDQKLLS YI QEHGGGS WRGLPAKAGLQRCGKS CRLR WI NYLRPDI KRGKFS SQEERTI I Q 80 GhMML4-D12 MQQS P CS DKVVLKKGP WTPEEDQKLLS YI QEHGGGS WRGLP AKAGLQRCGKS CRLRWI NYLRP DI KRGKF S S QEERTI I Q 80

Consensus mq q pcsdkv 1 kkgpwt peedqk1l syi qehgggswrgl pakaglqregkscrl r wi nylrpdikrgkfssqeerti i

Ga12G1199.1 LHALLGNR US AI AAHLP KRTDNEI KNYUNTQLKKRLTTI GI DPATHRP KTDTLGS TP KDAANLS HMAQWES ARLEAEARL 160 GhMML3_A12 LHALLGNR US AI AAHLP KRTDNEI KNYWNTQLKKRLTTI GI DP ATHRP KTDTLGS TP KDAANLS HMAQWES ARLEAEARL 160 GhMML4_D12 LHALLGNR US AI AAHLP KRTDNEI KNYWNTQLKKRL TKI GI DP ATHRP KTDTLGS TP KDAANLS HMAQWES ARLEAEARL 160

Consensus 1 hal 1 gnrwsai a ahl pkrtdneiknywnt qlkklt igidpathrpktdt gstpkdaanlshmaqesarleaearl

Ga12G1199.1 VRES KRVS NP PQNQF RF TS S S AP PLVSKI DVGL AHATKPQ CLDVLKAWQRVVTGLF TF NTDNLQS PTS TS SF TENTLPI S 240 GhMML3 A12 VRES KR VS NP P QNQF RF TS S S AP PL VNKI DVGL AHAT KP Q CLDVLKAWQR VVTGLF TF NTDNLQS P TS TS S F TENTLPI S 240 GhMML4_D12 VRES KR VS NP PQNQF RF TS S S AP PLVNKI DVGLAHATKPQCLDVLKAWQR VVTGLF TF NTDNLQS PTS TS S F TENRLPI S 240 Consensus vreskrvsnppqufrftsssapplv kidvglahat kpqcldvlkawqrvetglftfotdnlqsptstssften lpis

Ga12G1199.1 GhMML3 A12 Ri

Consensus svgfidsfvgnsnnscgnnwecvekssqua 1 qe $1 \mathrm{dns}$ mg

CMTYUI S

PQKMYS DTLMVCDS GD 305

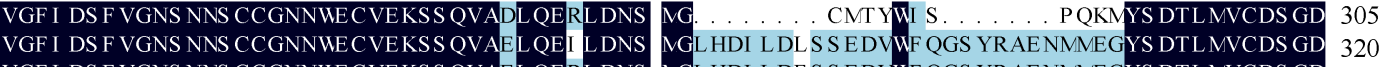
GL HDI LDF S SEDVWF QGS YRAENMMEGYS DTLMVCDS GD 320 y d t $1 \mathrm{mvcdsgd}$

Ga12G1199.1 HP KS LS MEPRQNF NVGTS NAS S F EENKNYUNNI LNF ANAS PS GS S VF 352

GhMML3_A12 HP KS LS MEPRQNF NVGTS NAS S F EENKNYWNNI LNF ANAS PS GS S VF 367

GhMML4_D12 HP KS LS MEPRQNF NVGTS NAS S F EENKNYWNNI LNF ANAS PS GS S VF 367

Consensus hpks l s me prqnfnvgt s nas sfeenknywn nil nfanas psgs svf

图 6 MYBMIXTA-like 基因在亚洲棉中的同源序列比对

Fig. 6 Homologous sequence alignment of MYBMIXTA-like in G. arboreum

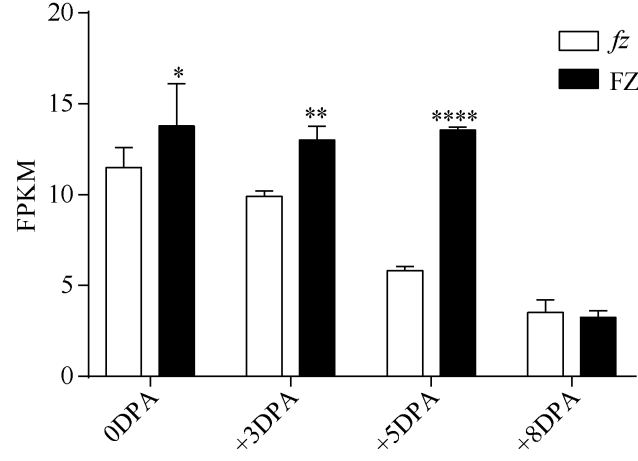

图 $7 G a 12 G 1199$ 在 $\mathrm{FZ}$ 和 $f z$ 材料中的表达差异

Fig. 7 Expression of Ga12G1199 in FZ and $f z$ materials $* P<0.05, * * P<0.01, * * * * P<0.0001$.

珠中表达量有显著差异。将qRT-PCR和RNA-seq中差 异基因表达量经 $\log _{2}$ 转化后做相关性分析, 所得 的皮尔逊相关系数为 0.89 (图8), 证明RNA-Seq结果 可信。

经 qRT-PCR 验证，细胞色素氧 化酶 P450 ( $G a 04 G 0014)$ 、甲基转移酶 $(G a 07 G 0568)$ 、转录因子 WD40(Ga07G1530)、蛋白受体激酶(Ga08G0121)、

二氢黄酮醇-4-还原酶(Ga09G0661)和谷胱甘肽S-转 移酶 (Ga11G2833) 在突变体 FZ中上调; 分子伴侣 $(G a 05 G 3965)$ 、钙联蛋白 $(G a 07 G 1742)$ 、转录因子 MYB108(Ga07G2088)、网状蛋白 $(G a 07 G 2611)$ 和 $\mathrm{NADH}$ 脱氢酶 $(G a 11 G 3670)$ 在突变体材料中下调。

\section{3 讨论}

棉纤维起始是决定纤维产量的关键过程。在过 去的 10 年中，许多参与棉纤维发育的基因已经被鉴

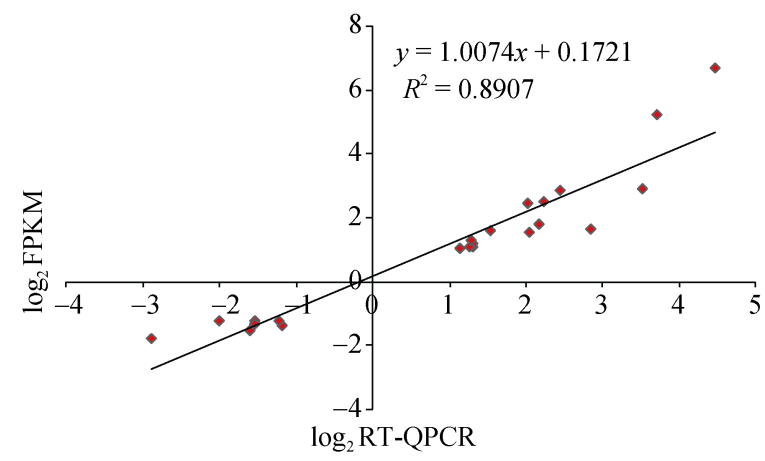

图 8 RT-QPCR (X-轴)结果与 RNA-seq (Y-轴)差异基因相关性分析 Fig. 8 Comparison of expression ratios from RT-QPCR (Y-axis) and transcriptomic (X-axis) profiling 散点图代表 RT-QPCR 与 RNA-seq 的差异基因相对表达量的 $\log _{2}$ 值。 Scatter plots represent $\log _{2}$ expression ratios calculated from RTQPCR and RNA-seq.

定出来。相比之下，对于野生型种皮上的短线发育了 解比较少。长纤维在生产上主要用于纺织, 短纤维在 生产上主要用于火药、造纸和医药用品，由于短纤维 一些特有性质和价值, 吸引了一些科学家研究其发 育机制 ${ }^{[19]}$ 。

植物激素例如赤霉素 $(\mathrm{GA}) 、$ 生长素、细胞分裂素、 油菜素内酯(BR)、脱落酸 $(A B A) 、 乙$ 烯、茉莉酸甲酯 (JA) 和水杨酸是植物内源小信号分子 ${ }^{[20]}$ 。许多研究证 明生长素在纤维发育过程中起重要作用。外源补充吲 哚乙酸(IAA)能弥补纤维伸长的缺陷性, 并且能显著 增加纤维的总体积 ${ }^{[21]}$ 。生长素响应蛋白 GhARF2 和 GhARF18, 在纤维起始的细胞中表达高, 当把这 2 个 生长素响应蛋白在拟南芥中超表达后, 能显著促进 拟南芥表皮毛起始, 说明 GhARF2 和 GhARF18 正调 
控棉花纤维细胞起始 ${ }^{[22]}$ 。与 GhARF2 和 GhARF18 作 用相反, INDOLEACETIC ACIDINDUCED PROTEIN 16 (GhIAA16)负调控纤维的起始和伸长。GhIAA16 在 野生型胚珠中表达非常低, 然而在无短线无长纤维 突变体中转录水平在开花后急剧升高 ${ }^{[23]}$, 这与本研 究结果一致。GaIAA16 在短线突变体 $+5 \mathrm{DPA}$ 的表达 量比野生型的高 4 倍。前人研究显示向体外离体培 养的胚珠中加入 $\mathrm{ABA}$, 纤维细胞的起始受到抑制, 而且 Ligon-lintless 1 突变体 0DPA 的胚珠中积累 ABA 的量比野生型的高 ${ }^{[24]}$ 。这些结果说明 ABA 负调控棉 花纤维起始。本研究结果显示, 与 ABA 信号传递相 关的基因表达量在突变体中明显升高, 与纤维起始 呈负相关的植物激素 ABA 响应因子(Ga11G3045、 Ga12G2331)在突变体短线起始期也显著的上调, 进 而抑制了短线纤维的起始。这些转录组分析结果需 要进一步的试验验证。

最近研究显示, 植物体内信号分子, 如钙离子 $\left(\mathrm{Ca}^{2+}\right)$ 和活性氧( $\left.\mathrm{ROS}\right)$, 特别是超氧阴离子 $\left(\mathrm{O}^{2-}\right)$ 和过 氧化氢 $\left(\mathrm{H}_{2} \mathrm{O}_{2}\right)$ 参与棉花纤维发育。当用 $\mathrm{H}_{2} \mathrm{O}_{2}$ 处理光 子突变体 $(N 1)$ 和短线突变体 (XinFLM) 时, 突变体纤 维在 ODPA 时开始起始, 说明 ROS 对纤维起始具有 促进作用 ${ }^{[25]}$ 。本研究显示参与活性氧清除的谷胱甘 肽转移酶(GST)基因在突变体 FZ 短线起始期明显升 高。 $\mathrm{Ca}^{2+}$ 也参与棉纤维细胞的起始, 与-1DPA 的胚珠 相比, ODPA 的胚珠中钙离子的积累明显升高, 基因 芯片分析结果显示, 参与钙离子信号转导的基因钙

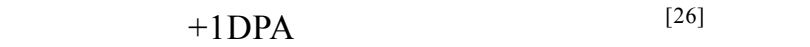
蛋白 $(\mathrm{CBL})$ 在 $\mathrm{Ca}^{2+}$ 信号转导过程中起重要作用, 其 表达量在短线突变体胚珠中下调了 2 倍, 与前人结 果一致。 $\mathrm{Ca}^{2+}$ 正调控纤维起始 ${ }^{[27-28]}$ 。

前人研究结果显示, GhMML3 (GhMYB25-like) 基因正调控陆地棉短线纤维起始, 而 GhMML4 基因 正调控陆地棉长纤维起始 ${ }^{[17-18]}$ 。而这 2 个基因在亚 洲棉中的同源基因 Ga12G1199 在短线突变体中的表 达量明显高于其在野生型中的表达量，该基因可能 负调控短线的发育。造成这种现象的原因可能是陆 地棉和亚洲棉短线发育机制不一样。

本文通过短线突变体及其野生型 4 个纤维发育 时期的 RNA-Seq 测序数据分析篮选到 4988 个差异 表达的基因, 其中上调表达的 2612 个，下调表达的 2376 个，但仅 $21.5 \%$ 的基因在棉花基因组数据库中找到 注释信息, 有大量未知基因信息存在。参与 KEGG 排名前 5 富集通路的基因, 如参与角质、木质素和蜡
质合成过程的基因( $G a 08 G 2220$, 细胞色素氧化酶)在 突变体(FZ)中下调, 说明这些基因可能正调控短线的 发育; 参与苯丙烷代谢和生物合成过程的基因 ( $G a 11 G 3625 、 G a 05 G 2018$, 过氧化物酶)在 FZ 中明显 上调, 说明这些基因可能负调控短线发育; 参与植物 激素信号转导途径中的乙烯响应因子相关基因 (Ga06G1125、Ga08G2804、Ga05G0163 和 Ga11G2673) 以及 $\mathrm{ABA}$ 合成和信号转导相关基因( $G a 02 G 1198$ 、 Ga07G0242、Ga07G0142、Ga08G2885 和 Ga11G3045) 在 FZ 短线起始期 $+5 \mathrm{DPA}$ 明显上调, 说明这些基因可 能负调控短线发育。在 91 个共有的差异基因中, 与 转座现象相关的基因 Cotton_newGene_252500 copia 型多蛋白, 转录因子 NAC1(Ga04G1773), 以及氧化 还原相关基因谷胱甘肽 S-转移酶(Ga11G2833)在 FZ 中明显上调，说明这些基因可能负调控短线发育; 而 NADPH 脱氢酶(Ga10G1419)基因, 与钲信号转导 相关基因(Ga07G1792)在 FZ 中下调，说明这些基因 正调控短线发育。

\section{4 结论}

短线突变体 $(\mathrm{FZ})$ 及其野生型 $(f z)$ 的表型差异为阐 明调控棉纤维发育的机制和品系间的形态差异提供 了信息。短线的起始在 $+3 \mathrm{DPA}$ 。造成短线纤维细胞在 突变体中未起始的原因是, 一些促进纤维伸长的基 因下调，而另外一些抑制纤维起始的基因上调。例如 参与蜡质合成的基因以及 $\mathrm{Ca}^{2+}$ 信号转导的基因在突 变体中都下调; 清除活性氧的基因以及参与 $\mathrm{ABA}$ 信 号转导的基因在突变体中上调。该研究对于理解亚洲 棉短线纤维起始的机制具有一定的理论意义, 对于 提高棉纤维产量和品质具有重要的实践意义。

\section{References}

[1] Lee J J, Woodward A W, Chen Z J. Gene expression changes and early events in cotton fibre development. Ann Bot, 2007, 100: 1391-1401.

[2] Kim H J, Triplett B A. Cotton fiber growth in planta and in vitro. Models for plant cell elongation and cell wall biogenesis. Plant Physiol, 2001, 127: 1361-1366.

[3] Turley R B, Kloth R H. Identification of a third fuzzless seed locus in upland cotton (Gossypium hirsutum L.). J Heredity, 2002, 93: 359-364.

[4] Arpat A B, Waugh M, Sullivan J P, Gonzales M, Frisch D, Main D, Wood T, Leslie A, Wing R A, Wilkins T A. Functional genomics of cell elongation in developing cotton fibers. Plant Mol Biol, 2004, 54: 911-929.

[5] Shi Y H, Zhu S W, Mao X Z, Feng J X, Qin Y M, Zhang L, Cheng J, Wei L P. Transcriptome profiling, molecular biological, 
and physiological studies reveal a major role for ethylene in cotton fiber cell elongation. Plant Cell, 2006, 18: 651-664.

[6] Yang S S, Cheung F, Lee J J, Ha M, Wei N E, Sze S H, Stelly D M, Thaxton P, Triplett B, Town C D. Accumulation of genome-specific transcripts, transcription factors and phytohormonal regulators during early stages of fiber cell development in allotetraploid cotton. Plant J, 2006, 47: 761-775.

[7] Wang M J, Tu L L, Yuan D J, Zhu D, Shen C, Li J Y, Liu F Y, Pei L L, Wang P C, Zhao G N, Ye Z X, Huang H, Yan F L, Ma Y Z, Zhang L, Liu M, You J Q, Yang Y C, Liu Z P, Huang F, Li B Q, Qiu P, Zhang Q H, Zhu L F, Jin S X, Yang X Y, Min L, Li G L, Chen L L, Zheng H K, Lindsey K, Lin Z X, Udall J A, Zhang X L. Reference genome sequences of two cultivated allotetraploid cottons, Gossypium hirsutum and Gossypium barbadense. Nat Genet, 2018, 51: 224-229.

[8] Du X, Huang G, He S, Yang Z, Sun G, Ma X, Li N, Zhang X, Sun J, Liu M, Jia Y, Pan Z, Gong W, Liu Z, Zhu H, Ma L, Liu F, Yang D, Wang F, Fan W, Gong Q, Peng Z, Wang L, Wang X, Xu S, Shang H, Lu C, Zheng H, Huang S, Lin T, Zhu Y, Li F. Resequencing of 243 diploid cotton accessions based on an updated a genome identifies the genetic basis of key agronomic traits. Nat Genet, 2018, 50: 796-802.

[9] Zhang T, Hu Y, Jiang W, Fang L, Guan X, Chen J, Zhang J, Saski C A, Scheffler B E, Stelly D M, Hulse-Kemp A M, Wan Q, Liu B, Liu C, Wang S, Pan M, Wang Y, Wang D, Ye W, Chang L, Zhang W, Song Q, Kirkbride R C, Chen X, Dennis E, Llewellyn D J, Peterson D G, Thaxton P, Jones D C, Wang Q, Xu X, Zhang H, Wu H, Zhou L, Mei G, Chen S, Tian Y, Xiang D, Li X, Ding J, Zuo Q, Tao L, Liu Y, Li J, Lin Y, Hui Y, Cao Z, Cai C, Zhu X, Jiang Z, Zhou B, Guo W, Li R, Chen Z J. Sequencing of allotetraploid cotton (Gossypium hirsutum L. acc. TM-1) provides a resource for fiber improvement. Nat Biotechnol, 2015, 33: 531-537.

[10] Islam M S, Fang D D, Thyssen G N, Delhom C D, Liu Y L, Kim $\mathrm{H}$ J. Comparative fiber property and transcriptome analyses reveal key genes potentially related to high fiber strength in cotton (Gossypium hirsutum L.) line MD52ne. BMC Plant Biol, 2016, 16: 1-19.

[11] Hande A S, Katageri I S, Jadhav M P, Adiger S, Gamanagatti S, Padmalatha K V, Dhandapani G, Kanakachari M, Kumar P A, Reddy V S. Transcript profiling of genes expressed during fibre development in diploid cotton (Gossypium arboreum L.). BMC Genomics, 2017, 18: 675.

[12] Trapnell C, Pachter L, Salzberg S L. TopHat: discovering splice junctions with RNA-Seq. Bioinformatics, 2009, 25: 1105-1111.

[13] Cole T, Adam R, Loyal G, Geo P, Daehwan K, Kelley D R, Harold P, Salzberg S L, Rinn J L, Lior P. Differential gene and transcript expression analysis of RNA-seq experiments with
TopHat and Cufflinks. Nat Protocols, 2012, 7: 562-578.

[14] Ogata H, Goto S, Sato K, Fujibuchi W, Bono H, Kanehisa M. KEGG: Kyoto encyclopedia of genes and genomes. Nucleic Acids Res, 1999, 27: 29-34.

[15] Minoru K, Susumu G, Yoko S, Masayuki K, Miho F, Mao T. Data, information, knowledge and principle: back to metabolism in KEGG. Nucleic Acids Res, 2014, 42: 199-205.

[16] Livak K J, Schmittgen T D. Analysis of relative gene expression data using real-time quantitative PCR and the 2(-Delta Delta C(T)) method. Methods, 2001, 25: 402-408.

[17] Wan Q, Guan X Y, Yang N N, Wu H T, Pan M Q. Small interfering RNAs from bidirectional transcripts of GhMML3_A12 regulate cotton fiber development. New Phytol, 2016, 210: 1298-1310.

[18] Wu H T, Tian Y, Wan Q, Fang L, Guan X Y, Chen J D. Genetics and evolution of MIXTA genes regulating cotton lint fiber development. New Phytol, 2018, 217: 883-895.

[19] Du S J, Dong C J, Zhang B, Lai T F, Du X M, Liu J Y. Comparative proteomic analysis reveals differentially expressed proteins correlated with fuzz fiber initiation in diploid cotton (Gossypium arboreum L.). J Proteomics, 2013, 82: 113-129.

[20] Daviere J M, Achard P. A pivotal role of DELLAs in regulating multiple hormone signals. Mol Plant, 2016, 9: 10-20.

[21] Chen Z J, Guan X Y. Auxin boost for cotton. Nat Biotechnol, 2011, 29.

[22] Xiao G H, He P, Zhao P, Liu H, Zhang L, Pang C, Yu J. Genome-wide identification of the $G h A R F$ gene family reveals that GhARF2 and GhARF18 are involved in cotton fibre cell initiation. $J$ Exp Bot, 2018, 69: 4323-4337.

[23] Han, X Cloning and expression analysis of novel Aux/IAA family genes in Gossypium hirsutum. Genes, 2012, 503: 83-91.

[24] Gilbert M K, Bland J M, Shockey J M, Cao H, Hinchliffe D J, Fang D D, Naoumkina M. A transcript profiling approach reveals an abscisic acid-specific glycosyltransferase (UGT73C14) induced in developing fiber of ligon lintless-2 mutant of cotton (Gossypium hirsutum L.). PLoS One, 2013, 8.

[25] Zhang D Y, Zhang T Z, Guo W Z. Effect of $\mathrm{H}_{2} \mathrm{O}_{2}$ on fiber initiation using fiber retardation initiation mutants in cotton (Gossypium hirsutum). J Plant Physiol, 2010, 167: 393-399.

[26] Taliercio E W, Boykin D. Analysis of gene expression in cotton fiber initials. BMC Plant Biol, 2007, 7: 22.

[27] Kudla J, Batistic O, Hashimoto K. Calcium signals: the lead currency of plant information processing. Plant Cell, 2010, 22: 541-563.

[28] Steinhorst L, Mähs A, Ischebeck T, Zhang C X, Zhang X X, Arendt S, Schültke S, Heilmann I, Kudla J. Vacuolar CBLCIPK12 $\mathrm{Ca}^{2+}$-sensor-kinase complexes are required for polarized pollen tube growth. Curr Biol, 2015, 25: 1475-1482. 